\title{
LA IMAGEN DE ESPAÑA EN LAS ROSAS DE PIEDRA Y LAS ROSAS DEL SUR DE JULIO LLAMAZARES* \\ THE IMAGE OF SPAIN IN LAS ROSAS DE PIEDRA AND LAS ROSAS DEL SUR BY JULIO LLAMAZARES
}

\author{
Alida Ares Ares \\ Universidad de Trento
}

RESUMEN

En este artículo analizamos la obra de Julio Llamazares publicada en dos volúmenes, Las rosas de piedra (2008) y Las rosas del sur (2018), considerando su carácter sistémico como un único libro de viajes, poniendo de relieve los elementos discursivos y lingüísticos característicos y enfocándonos principalmente en su contenido temático, en la imagen de España que resulta del mismo. Para ello, en primer lugar, observamos los objetivos, la estructura, las características descriptivas de la obra y los rasgos pragmalingüísticos y léxicos y, en segundo lugar, nos centraremos en su contenido temático.

Palabras Clave: Julio Llamazares, literatura española contemporánea, literatura de viajes, viaje por España, patrimonio artístico.

\section{ABSTRACT}

In this article we analyze the work of Julio Llamazares published in two volumes, Las rosas de piedra (2008) and Las rosas del sur (2018), considering its systemic character, as a single travel book, highlighting the discursive and linguistic elements characteristic of it and focusing mainly on its thematic content, the image of Spain that results from it. For this purpose, first of all, we shall analyze, in the first place, the objectives, the structure, the descriptive characteristics of the work and the pragmalinguistic and lexical traits and, secondly, we will focus on its thematic content.

KEY WORDS: Julio Llamazares, contemporary Spanish literature, travel literature, travel through Spain, artistic patrimony.

\footnotetext{
* Recibido: 18-03-2018 / Aceptado: 18-09-2019.
} 


\section{INTRODUCCIÓN}

En octubre de 2018 se publicó Las rosas del sur ${ }^{1}$, el volumen que recoge los viajes de Julio Llamazares por las catedrales del sur de España y que completa Las rosas de piedra, publicado diez años atrás ${ }^{2}$. El primer volumen comprendía las visitas a las cuarenta y dos catedrales de la mitad norte, y estaba estructurado en seis capítulos correspondientes a los seis viajes que el escritor realizó para ello, titulados: «Galicia», «El reino perdido», «Donde la Vieja Castilla», «Vascos, navarros y riojanos», «Aragón de Norte a Sur» y «Las seos de Cataluña». El segundo, dividido en ocho capítulos, se corresponde con otros tantos viajes que abarcan las restantes treinta y tres catedrales: «Madrid, tres más una», «Por tierras de Extremadura», «La Mancha y alrededores», «Levante: moros y cristianos», «Las catedrales del mar (Baleares)», «El valle del Guadalquivir», «La frontera de Granada» $\mathrm{y}$ «Las catedrales del mar (Canarias)».

Los libros de viajes se encuentran entre las mejores obras de Llamazares: El río del olvido (1990), Trás-os-Montes (1998), Cuaderno del Duero (1999) y, más recientemente, Atlas de la España imaginaria (2015), El viaje de Don Quijote (2016) y la serie Los caminos de la picaresca (El País, agosto de 2018) dan buena prueba de su dominio del género. Pero en esta ocasión el viaje y la redacción del mismo se convierten en una empresa excepcional realizada durante casi diecisiete años, entre el 1 de septiembre de 2001 y el 30 de marzo de 2018, y que ha supuesto un recorrido por España de más de veinte mil kilómetros repartidos en catorce viajes. Estos comprenden la visita a las setenta y cinco catedrales distribuidas por toda la geografía, considerando tales aquellas en las que actualmente tiene su cátedra el obispo, con la salvedad de la de Roda en Huesca, que ha dejado de serlo, y la de Mejorada del Campo de Justo Gallego, que el autor incluye por su singularidad como un epílogo quijotesco a las catedrales de la Comunidad de Madrid.

Pero Llamazares no solo describe las catedrales, sino que traza un panorama general del territorio donde se hallan: nos habla de la geografía, el paisaje y la economía de la región, de la ciudad episcopal y del carácter de sus gentes, de rincones particulares, museos y obras arquitectónicas o artísticas, y también de hoteles, restaurantes y bares que visita durante el día y la noche que permanece en cada lugar. Sin embargo, no se trata de una guía turística, en todo caso se podría usar como una guía alternativa, como las obras que consulta también el mismo autor para organizar sus itinerarios,

\footnotetext{
${ }^{1}$ J. Llamazares, Las rosas del sur, Barcelona, Alfaguara, 2018.

2 J. Llamazares, Las rosas de piedra [Barcelona, Alfaguara, 2008], que citaremos siguiendo la edición de Barcelona, Penguin Random House Grupo Editorial, 2016.
} 
entre ellas la de Avelino Hernández, Donde la vieja Castilla se acaba: Soria (2015), que considera un clásico de los libros de viajes ${ }^{3}$.

El libro en dos volúmenes de Llamazares recuerda las obras renacentistas por su arquitectura y su contenido humanístico y los libros de viajes de los escritores románticos, ya que recoge las propias vivencias del autor, su pensamiento, sus impresiones y sentimientos durante el viaje y va más allá del tiempo en que se realiza. Es un libro que muestra la pasión del escritor por la historia y el arte y por esos edificios singulares, las catedrales, que surgieron en un momento determinado de la historia de las ciudades y han sufrido con ellas continuas transformaciones a lo largo del tiempo, y al mismo tiempo muestra su interés por los paisajes y la idiosincrasia de las diferentes regiones de España.

\section{Propósito y objetivos}

El carácter de esta empresa que ocupa más de mil cuatrocientas páginas distribuidas en los dos volúmenes, lo sintetiza el autor en el Preámbulo:

Este es un viaje en el tiempo y en la geografía. En el tiempo, hacia el pasado, hacia la época en la que se construyeron esos maravillosos edificios que han sobrevivido al tiempo como representaciones de la ciudad de Dios en la tierra y que conocemos como catedrales; y, en la geografía, a través de un país que es un mosaico de regiones tan diferentes como sus paisajes ${ }^{4}$.

El viaje nace de una imagen fascinante: la visión, cuando era niño, de una catedral, la de León, con sus vidrieras reflejadas en la pila del agua bendita, removida por la mano de su padre, como en un caleidoscopio ${ }^{5}$. Esa imagen se convierte en el eje central de la obra. No solo retorna de manera explícita con frecuencia en el interior de las catedrales (León, Murcia, Mallorca, Córdoba...), sino que la visión de la realidad compleja de España que nos muestra es también multiforme y caleidoscópica. A la atracción que siente por esos templos que lo deslumbraron desde niño, se une el gran interés que se muestra en toda su obra por los mundos que están desapareciendo o que van quedando al margen de la realidad:

Qué es lo que me llevó a elegir estos edificios para este nuevo viaje literario (...). Intuyo que la atracción que siempre me han producido las catedrales desde que, cuando era niño,

\footnotetext{
${ }^{3}$ «Más que un libro, es una declaración de amor, una introspección poética, un recorrido por una tierra que es más que eso, una exaltación, en fin, de todo lo que la literatura tiene de misterioso y emocionante» (A. Hernández, Donde la vieja Castilla se acaba: Soria, León, Rimpego, 2015, Prólogo, p. 3).

${ }^{4}$ J. Llamazares, Las rosas de piedra, ob. cit., p. 17.

${ }^{5}$ El episodio aparece en J. Llamazares., Escenas de cine mudo, Barcelona, Seix Barral, 1994 [Cit. ed. de 2004, pp. 185-191].
} 
entré por primera vez en la de León y también, acaso por la preferencia que siento por esos mundos que han quedado a desmano de la historia o simplemente de la realidad ${ }^{6}$.

Fulcanelli en el íncipit de El misterio de las catedrales (1929) ${ }^{7}$, siguiendo la imagen clásica de la obra de creación como un libro, que hallamos ya en Dante ${ }^{8}$, las define como «bellos libros de imágenes que despliegan hacia el cielo sus hojas esculpidas en piedra». En el mismo pasaje de la obra, que Llamazares cita al inicio de Las rosas de piedra, Fulcanelli revela la impresión que le produjo a él también la vista de una catedral gótica cuando era niño:

La más fuerte impresión de nuestra primera juventud -teníamos a la sazón siete años-, de la que conservamos todavía vívido un recuerdo, fue la emoción que provocó, en nuestra alma de niño, la vista de una catedral gótica?.

El objetivo que se propone Llamazares es el de leer, «deshojar», las catedrales españolas como si fueran «rosas de piedra», una metáfora poética que sugiere que desea indagar a través de ellas, captar su esencia, su misterio, y vivir desde dentro la experiencia para ofrecérsela luego a los lectores:

A deshojarlas como si fueran rosas de piedra, enormes rosas arquitectónicas surgidas en nuestras ciudades hace ya cientos de años y hoy olvidadas por la mayoría, he dedicado este libro ${ }^{10}$.

En la Nota del autor de Las rosas del sur advierte que se trata de un libro de viajes, «no de arte ni de historia, ni mucho menos de espiritualidad». Pero podemos considerar la advertencia como un recurso de modestia, pues el libro muestra al mismo tiempo su pasión por las dos primeras y su interés por la tercera, y constituye una valiosa fuente documental como testimonio social de esta época, aunque la intención que mueva al autor sea esencialmente literaria, como precisa en el Preámbulo:

Sin otra voluntad que la viajera y sin otra intención que la literaria. Esa que sigue la estela de los antiguos viajeros, aquellos que partían por partir, en palabras de Rimbaud, o que preferían un mal camino a una buena venta, en las de Cervantes. Los viajeros, en suma, que iban buscando la magia que el mundo ofrece a los que andan ${ }^{11}$.

Como un moderno Rimbaud, el autor parte por el placer del viaje, para descubrir y regresar trayendo consigo el conocimiento y la magia de un mundo desconocido, y,

${ }^{6}$ J. Llamazares, Las rosas de piedra, ob. cit., p. 18.

${ }^{7}$ Fulcanelli, El misterio de las catedrales y la interpretación esotérica de los símbolos, París, 1929, cap. 1. Disponible en http://10millibrosparadescargar.com [consultado en 07/11/ 2018].

${ }^{8}$ D. Alighieri, La Divina Commedia, Paradiso, xxxIII, pp. 82-90. Disponible en: https://it.wikisource.org/ wiki/Divina_Commedia/Paradiso/Canto_xxxIII.

${ }^{9}$ Fulcanelli, El misterio de las catedrales, ob. cit., Incipit cap. 1.

${ }^{10} \mathrm{~J}$. Llamazares, Las rosas de piedra, ob. cit., p. 18.

${ }^{11}$ J. Llamazares, Las rosas de piedra, ob. cit., p. 19. 
como su admirado don Quijote ${ }^{12}$, lo hace introduciéndose con inquietud en un mundo que ha sido despojado de su significado y de sus valores. Las catedrales, afirma, «no son ya más que espejismos, reliquias de un tiempo ido que quedó aprisionado en ellas» ${ }^{13}$.

Además del texto de Fulcanelli, Llamazares cita al frente de su obra el pasaje inicial de La época de las catedrales de Jacques Duby ${ }^{14}$, que es una recreación del mundo medieval de finales del siglo $x$, esa época a la que pone rumbo cuando emprende su travesía:

Muy pocos hombres -las soledades se extienden hacia el oeste, hacia el norte, hacia el este, inmensas, y terminan por invadirlo todo-, tierras yermas, ciénagas, ríos vagabundos [...] Un mundo salvaje. Un mundo acechado por el hambre [...]. Sin embargo, desde hace cierto tiempo, movimientos imperceptibles empujan a esta humanidad miserable a emerger lentamente de la barbarie ${ }^{15}$.

Un periplo tan largo requiere planificación, itinerarios, mapas, bibliografía. Pero el autor sabe que el viaje que se planifica es solo subsidiario del real, y que no se ha de ir sabiendo lo que se va a ver. Como afirma Claudio Magris, otro gran viajero: «Viajar es una experiencia musiliana, confiada al sentido de las posibilidades más que al principio de la realidad ${ }^{16}$. El devenir del viaje y el azar son los que mueven también al viajero Llamazares y harán que se desvíe para visitar lugares no incluidos inicialmente en su itinerario, como la excatedral de Roda de Isábena y la de Mejorada del Campo, o que personas que se cruzan en su camino lo entretengan o lo dirijan a otros sitios que no pensaba visitar, como cuando en Salamanca el vigilante de la puerta de la catedral le aconseja ir a ver una exposición en la Torre Mocha:

- No lo sé, lo pensaré - le agradece su consejo el viajero despidiéndose. Pero no lo piensa mucho. En cuanto sale a la calle se encuentra la Torre Mocha de frente y, cuando se quiere dar cuenta, está ya dentro de ella ${ }^{17}$.

Llamazares posee una amplia cultura humanística: sus intereses abarcan la literatura, la historia, la sociología, el arte y la filosofía, tal como se puede apreciar en sus anteriores libros de viajes, novelas, ensayos y artículos periodísticos. En cada

\footnotetext{
${ }^{12}$ Acerca de la influencia de El Quijote en la literatura de viajes de Llamazares véase A. Ares Ares, «En la estela de Cervantes: similitudes y diferencias entre La ruta de Don Quijote de Azorín y El viaje de Don Quijote de Julio Llamazares», en J. Ferrándiz Lozano y J. Payá Bernabé (eds.), Azorín, clásico y moderno. Número monográfico de Canelobre: Revista del Instituto Alicantino de Cultura «Juan Gil-Albert», 67 (2017), pp. 130-145.

${ }^{13}$ J. Llamazares, Las rosas del sur, ob. cit., p. 18.

${ }^{14}$ G. Duby, La época de las catedrales (Arte y sociedad, 980-1420), Madrid, Cátedra, 1993.

${ }^{15} \mathrm{~J}$. Llamazares, Las rosas de piedra, ob. cit., pp. 13-14.

${ }^{16}$ C. Magris, El infinito viajar, Barcelona, Anagrama, 2008. En Prefacio, p. 17.

${ }^{17}$ J. Llamazares, Las rosas de piedra, ob. cit., p. 196.
} 
ocasión se documenta con la bibliografía en torno al tema, y esa literatura, que se incorpora a su mirada personal y enriquece su imaginación, se transmite luego en su trabajo. Además de las obras de Fulcanelli y Duby, y de los libros de historia y arte que aparecen citados en la obra, como los catálogos monumentales de Gómez-Moreno $(1870-1970)^{18}$, el autor ha tenido en consideración libros de filosofía relacionados con el paisaje y la búsqueda de la belleza, como Lo bello y lo siniestro (1982) y La funesta manía de pensar (2018), de Eugenio Trías, y otros libros de viajes, como Imágenes de Suecia (2018), de Lars Gustaffson y Annetta Blamquist, Cartas de la época de Ibiza (2008) de Walter Benjamin ${ }^{19}$, y el de Avelino Hernández, citado arriba, del que toma el título para su tercer viaje: «Donde la vieja Castilla», así como Notas de andar y ver (1988) de Ortega y Gasset y Andanzas y visiones españolas (1922) de Unamuno, que cita en sus visitas a Sigüenza y Ávila, respectivamente.

En realidad, la obra entera es un homenaje a los escritores españoles que nacieron, vivieron o escribieron acerca de las catedrales y los lugares en que se hallan. Desde Cervantes, a quien encontramos ya en el preámbulo y luego en Zaragoza y en La Mancha, a tantos otros poetas, novelistas o ensayistas como Álvaro Cunqueiro en Mondoñedo, Clarín en Oviedo, Claudio Rodríguez en Zamora, Federico Muelas en Cuenca, Ausiàs March en Valencia, Marià Villangómez en Ibiza, Federico García Lorca en Guadix, etcétera. A algunos les ha dedicado el capítulo, como «La patria de Miguel Hernández» en Orihuela o «La sombra de Machado» en Baeza. Este, por ser uno de sus poetas predilectos, lo acompaña durante todo el recorrido. Hay también referencias a autores extranjeros, como en el capítulo dedicado a la catedral de Pamplona, «La sombra de Hemingway», donde se incluye además una cita de Victor Hugo ${ }^{20}$.

Durante el viaje va adquiriendo nuevos libros, generalmente estudios y guías de las catedrales de autores locales, que compra, lee y comenta in situ, a veces incluso con el propio autor ${ }^{21}$, lo cual contribuye, junto con las explicaciones de los guías, religiosos o estudiosos de arte con los que se encuentra, a incrementar la polifonía coral de la obra y a ofrecer al lector una visión múltiple y poliédrica de cada lugar.

\footnotetext{
${ }^{18}$ M. Gómez-Moreno, Catálogo monumental de España (1870-1970), Madrid, Ministerio de Educación y Ciencia. Servicio Nacional de Información Artística (1967) [correspondiente a la provincia de Salamanca], y Catálogo monumental de España (1870-1970), Madrid, Mateu, 1903 [correspondiente a la provincia de Ávila]. Disponibles en: http:/ / biblioteca.cchs.csic.es (consultados el 16/01/2019). El autor los cita en la visita a la catedral de Ciudad Rodrigo (LRP: 205) y a la de Ávila (LRP: 290), respectivamente.

${ }^{19} \mathrm{El}$ autor cita estos libros entre los que ha manejado en una videoentrevista con Berna González Arbour, «¿Qué está leyendo Julio Llamazares?», publicada en El País el 14/9/2018.

${ }^{20}$ Alude de manera implícita a Fiesta (1926) de Hemingway y Viaje a los Pirineos y los Alpes (1890) de Victor Hugo.

${ }^{21}$ J. Llamazares, Las rosas del sur, ob. cit., p. 254 y ss.
} 


\section{Desarrollo y estructura de la obra}

Llamazares hace la distribución de los catorce viajes que componen la obra de acuerdo con la delimitación por provincias eclesiásticas, que a su vez sigue la de los romanos, ya que considera artificial la actual diferenciación administrativa. $Y$ en cada uno de los viajes, que comprende la visita a las diversas catedrales de una diócesis, va describiendo el paisaje y la topografía de la región que atraviesa, considerando también su estado de desarrollo agrícola e industrial. Al llegar a la ciudad se dirige a la catedral y observa en primer lugar el exterior, sus volúmenes y las características arquitectónicas más sobresalientes. Una vez dentro, describe la planta y los espacios interiores y da una primera vuelta de reconocimiento que comienza, generalmente, por la nave de la Epístola, prosigue por la girola y la nave del Evangelio, para regresar al punto de partida.

Su mirada es contemplativa, pero, al mismo tiempo, escrutadora, reflexiva y crítica. No solo se interesa por la catedral con sus obras de arte y su historia en relación con la ciudad y el territorio que la rodea, sino también por los vínculos espirituales que todavía mantiene la población del lugar con ella. Estos vínculos han ido disminuyendo debido al cambio de mentalidad de la sociedad y a otros obstáculos materiales, como la exigencia de la mayoría de los cabildos del pago de la entrada a los visitantes y la programación de los oficios a horas intempestivas, cuando ya se han ido aquellos. $\mathrm{Al}$ autor le interesa sobre todo el aspecto humano de las gentes que encuentra, y por ello viaja de incógnito, ya que es reveladora la actitud de acogida o de indiferencia, incluso de recelo, que muestran sacerdotes, sacristanes o empleados de los museos cuando el visitante se acerca a ellos y les interroga sobre determinadas cuestiones, o cuando permanece en el templo más de lo que suele ser habitual. En las catedrales más visitadas por los turistas (Madrid, Sevilla, Córdoba, Granada, Barcelona...), observa también el comportamiento de estos, generalmente inapropiado en relación al lugar, y dialoga también a menudo con los mendigos y las gentes del lugar que se encuentran en las inmediaciones del templo, para conocer sus opiniones.

Al mediodía sale a comer, y describe el ambiente de las calles y de los restaurantes. En alguna ocasión se cita con algún amigo con el que intercambia sus impresiones. Tras el almuerzo regresa a la catedral y visita el museo diocesano y de nuevo el templo. Lo hace con la ayuda de algún libro o siguiendo las explicaciones de un guía, o incluso, a veces, con una audioguía. Durante esta segunda visita se recrea ante algunos retablos e imágenes que lo atraen por su singular belleza, reflexiona sobre la historia de los personajes allí enterrados, observa con incredulidad las reliquias y se regocija con las leyendas o vidas de santos que despiertan su curiosidad. También asiste a las funciones religiosas (misas, rosarios, bodas, funerales) y repara en la actitud 
de los devotos que acuden a ellas. Cuando todos se han ido, él se demora en las naves vacías hasta que el recinto va quedando a oscuras o en penumbra. Luego sale a la luz y da un paseo hasta algún lugar donde tomar apuntes y poder admirar el paisaje en torno a la ciudad mientras atardece. Después de cenar, solo o acompañado por algún amigo, da otro paseo, entra en algún bar y describe el ambiente y el paisaje nocturno de la ciudad.

El orden se repite casi inalterado en cada relato, lo que hace que el lector tenga la impresión de acompañar al viajero durante todo el día y por todo el viaje comprendido en cada capítulo, que incluye la visita a varias catedrales. A ello contribuye la estructura formal circular del relato y el esquema temporal (un día para cada catedral, dividido en tres partes: mañana, tarde y noche) y la repetición de las acciones: por la mañana, viaje de una ciudad a otra y visita a la catedral; al mediodía, comida y paseo por la ciudad; por la tarde, visita al museo y la catedral; al atardecer, paseo; y por la noche, cena y paseo. Un tiempo cíclico marcado dentro del templo por la luz del sol que gira en torno a él penetrando a través de ventanales, rosetones y vidrieras e iluminando las diferentes naves y capillas en las distintas horas del día hasta el atardecer, cuando deja las naves en penumbra. Es la misma luz que buscaban los arquitectos de las catedrales góticas, la que disuelve y reverbera los colores en las vidrieras mostrando la maravilla de la labor del artista, la misma que en la teología mística del cristianismo simboliza la contemplación espiritual (el «río de luz», «la rosa de los beatos», en la visión del empíreo dantesco) $)^{22}$. La catedral que se alza desde la tierra hacia el cielo es el triunfo de la perfección espiritual y el reflejo de la armonía del cosmos, «la ciudad de Dios», que representa el mundo, la creación del gran Arquitecto del Universo, como recuerda el autor en la catedral de León ${ }^{23}$ :

[...] La impresión que produce es la de estar en un sueño. Un sueño que va creciendo a medida que la vista se desliza por los muros, de abajo arriba y de un lado a otro, descifrando los motivos de una iconografía, que como el mundo en la religión, se divide y se organiza en tres planos diferentes: abajo los vegetales, en medio el mundo animal, y en lo más alto del todo, el sobrenatural o místico. Es decir, la célebre pirámide religiosa tan del gusto del medievo ${ }^{24}$.

La concepción del tiempo cíclico determinado por la naturaleza con la repetición de los días y las estaciones es también la que sustenta la idea del «eterno retorno», la duración eterna. Y es la filosofía neoplatónica del homo viator ${ }^{25}$, ese viajero que se

\footnotetext{
${ }_{22}^{22}$ «Le faville tornano poi a sprofondarsi nel fiume di luce» (DANTE, Paradiso, Canto xxx, vv. 46-81).

${ }^{23}$ San Agustín, La ciudad de Dios, Madrid, Biblioteca de Autores Cristianos, 2009.

${ }^{24}$ J. Llamazarez, Las rosas de piedra, ob. cit., p. 128.

${ }^{25}$ Plotino (203-270) enseñaba que el hombre, en tanto es un ser espiritual, tiene como último fin (o destino) de esta vida el retorno al Uno del que procede. Ob. cit. en Bueno, G., «Homo viator. El viaje y el camino». Prólogo a P. Pisa, Caminos reales de Asturias, Oviedo, Pentalfa, 2000.
} 
desplaza sobre los acontecimientos y civilizaciones mientras el tiempo corre bajo sus pies:

El espectáculo del atardecer es algo así como el contrapunto de la creación del mundo que el viajero acaba de ver en el interior de aquel [del museo de la catedral]. La Gerona del siglo XXI, con sus torres y edificios, parece quieta en este momento, indecisa entre la luz y la penumbra de una noche que ya llega recordando que todo es un sucederse de vida y muerte, de luz y de oscuridad, como lo representó hace siglos el anónimo autor de La creación del mundo imaginando cómo sería el primer día del universo ¡Qué sensación de fugacidad!26

La arquitectura de la obra de Llamazares se conforma a esta filosofía: relato circular marcado por el curso solar que va girando en torno e iluminando a cada una de las catedrales, la ciudad y los alrededores, y que se va desplazando en el espacio, por la geografía española, y en el tiempo, en su historia. La concepción del viaje es también circular: el viajero, como el protagonista homérico, sale de Madrid, donde reside, y regresa a casa de cada uno de los catorce viajes; mientras que la subdivisión geográfica en provincias eclesiásticas constituye un puzle de otras tantas piezas que, a medida que avanza y se amplía, de oeste a este y de norte a sur, va configurando el mapa de la nación.

\section{Características descriptivas}

La secuencia textual envolvente es la descripción de los lugares y lo que se encuentra en ellos, como corresponde a los libros de viajes, aunque el autor alterna la descripción con la narración y el diálogo. Dentro de la descripción encontramos diversos tipos: la descripción de monumentos y obras de arte, que adquiere en esta obra especial relevancia por ser las catedrales el objetivo del viaje, la relacionada con las ciudades y el paisaje, y la de la caracterización de personajes.

La técnica descriptiva de las catedrales sigue un orden que va del exterior al interior y de lo general a lo particular. Comienza el autor describiendo la fachada principal de la catedral, generalmente orientada hacia el oeste, y al entrar se sitúa a los pies de la nave central, frente al altar mayor, para observar la forma arquitectónica de su planta y alzado y las proporciones del templo ${ }^{27}$. Durante su recorrido, como el arqueólogo que desvela la complejidad estratificada de un yacimiento, va descubriendo las diversas capas -estilos arquitectónicos, historia, obras de arte, hagiografía,

\footnotetext{
${ }^{26}$ J. Llamazares, Las rosas de piedra, ob. cit., p. 660.

${ }^{27}$ «Y teniendo las basílicas proporciones y formas del cuerpo humano, del mismo modo que la cabeza del hombre es el principal miembro del mismo, así la capilla mayor se ha de construir como principal miembro y cabeza del templo» (Di Giorgio Martini, F., Trattati di Architettura, Ingenieria e Arte Militare, Ed. Corrado Maltese, Milano, Il Polifilo, 1967).
} 
leyendas, creencias populares- que conforman las catedrales, y al tiempo que nos va proporcionando una información preciosa y detallada va depositando sobre ellas su mirada poética. El discurso fluye como un diálogo personal del autor-viajero con el arte y la historia que atesoran los templos:

Una catedral [la de Santiago] que es como la mayoría de ellas, el resumen de muchas catedrales superpuestas, desde aquel templo inicial que ordenó construir el rey Alfonso II el Casto a raíz del descubrimiento de los restos del apóstol y en torno al que surgiría la ciudad de Compostela. Por si faltara algo el viajero accede a ella por la puerta más hermosa de la Tierra: el pórtico de la Gloria, la obra en piedra más fabulosa de todas las de su estilo posiblemente en el mundo ${ }^{28}$.

En la descripción de elementos arquitectónicos de interiores, la materia, las formas, colores y estilos se mueven y amoldan en cada ocasión a la mirada del sujeto, como cuando describe la luz que penetra a través de cimborrios reverberando en las vidrieras, que crea en el interior de las naves imágenes caleidoscópicas entre realidad y ensoñación ${ }^{29}$, como la cúpula en la capilla de los Vélez de la catedral de Murcia:

[...] semeja un caleidoscopio, tal es su altura y profundidad, y al mismo tiempo un pozo invertido, un elegante y airoso pozo de piedra que da vueltas al mirarlo merced a las muchas luces que entran por sus vidrieras y por la que recibe de la catedral [de Murcia] [...] La vista del visitante no se despega de ese magnífico caleidoscopio que enfoca el cielo y de la maravillosa estrella que lo corona engarzando los nervios de las columnas que la sostienen ${ }^{30}$.

Otra característica de sus descripciones es el perspectivismo, la observación de los espacios mientras va acercándose a ellos, como en un travelling cinematográfico, o mirando desde abajo y desde arriba, como en el párrafo anterior donde el cimborrio se vuelve un pozo invertido. Un ejemplo de ambos recursos lo encontramos en la descripción de la catedral de Gerona, que se eleva sobre una escalinata de cien peldaños:

Uno a uno el viajero asciende la escalinata, que es ancha como una grada, mientras contempla cómo la catedral se va agrandando ante él a medida que se aproxima a ella [...] ¡Qué vista tan espectacular! Abajo, frente a sus pies, la escalinata desciende vertiginosa hacia la pequeña plaza que se abre justo al fondo, aprisionada entre los edificios como si fuera un pozo cuadrado $[\ldots]^{31}$.

En la descripción de las obras de arte, combina la información detallada con percepciones sensoriales y emociones que le provoca su contemplación y, en particular, su perfección y belleza, como la sillería del coro de la catedral de Sevilla:

\footnotetext{
${ }^{28}$ J. Llamazares, Las rosas de piedra, ob. cit., p. 27.

${ }^{29}$ Unamuno la define «una luz no usada» en En torno al casticismo, Barcelona, «Biblioteca Moderna de Ciencias Sociales» [dir. S. Valentì i Camps], 1902, vol. 4, cap. 4. 3. Disponible en: htpp:/www. cervantesvirtual.com. (consultado el 11/11/2018).
}

${ }^{30} \mathrm{~J}$. Llamazares, Las rosas del sur, ob. cit., p. 335.

${ }^{31}$ J. Llamazares, Las rosas de piedra, ob. cit., p. 646. 
El viajero sigue en el cielo mirando esta fantasía tallada en el siglo xv [...] Solamente el facistol y el templete con la imagen de la Virgen obra de Bautista Vázquez, escultor salmantino del XVI, ya sirven para elevar este coro mudéjar, único al parecer en su estilo, a la categoría de único, pero es que además los asientos, que son ciento veintisiete en total, componen una partitura que no necesita casi de voces para oír su música ${ }^{32}$.

La música que suena en ocasiones en el interior del templo se integra en sus descripciones. A veces es una música de fondo, otras algún ensayo o un concierto, como el del organista Gereon Krahforst en la catedral de Alcalá, que con su virtuosismo hace vibrar e inunda de música la catedral entera:

La música torrencial se apodera de las naves y las bóvedas, retumba como un gran trueno, se diluye por capillas y pasillos conmocionando a un público que asiste absorto a las evoluciones del organista en su inalcanzable púlpito, cerca de las altas bóvedas, desde donde las notas caen como una cascada ${ }^{33}$.

Llamazares posee una sensual pasión por la concreción física de las formas, los colores, los detalles. Muchas de las cosas y materias que describe suelen quedar envueltas por esa luz corpórea y espiritual a la vez, sobre todo las imágenes talladas de madera, como la Virgen de Andorra, de la Seo de Urgel:

Esta Virgen que preside el presbiterio y la catedral entera es tan hermosa y tan sugerente que atrae todas las miradas, como le ocurre ahora al viajero, que la mira emocionado por su impasible policromía perfecta (roja y blanca toda ella), por su serenidad y por la majestad del Niño ${ }^{34}$.

O la pequeña Inmaculada de Alonso Cano de la catedral de Granada, en el capítulo que titula, precisamente, «Las Vírgenes granadinas», y que le recuerda a su madre:

[...] la pequeña Inmaculada es tan hermosa que todas las demás Vírgenes sobran, pues ni a hacerle sombra alcanzaría ninguna. El viajero, emocionado, se queda un rato ante ella extasiado por esa imagen con la que su autor logró la perfección suprema. Definitivamente, su madre tuvo el mejor nombre, piensa el viajero mientras contempla esta Inmaculada cuya serenidad tanto le recuerda a ella ${ }^{35}$.

Pero a la vez su mirada es crítica, y muestra el disgusto ante añadidos y superposiciones que rompen la armonía y, sobre todo, ante la violación o adulteración de obras de arte por motivos de credo religioso, como en la mezquita de Córdoba, donde el enfrentamiento entre culturas y fes llevó a profanarla edificando una catedral en su interior:

\footnotetext{
${ }^{32}$ J. Llamazarez, Las rosas del sur, ob. cit., p. 491.

${ }^{33}$ J. Llamazares, Las rosas del sur, ob. cit., p. 66.

${ }^{34}$ J. Llamazares, Las rosas de piedra, ob. cit., p. 635.

${ }^{35}$ J. Llamazares, Las rosas del sur, ob. cit., p. 610.
} 
Durante todo el día, el viajero se debatirá en ese malestar estético que el contraste entre las dos culturas y los dos credos aquí enfrentados le producirá cada vez que lo descubra ${ }^{36}$.

Mientras visita las catedrales, de tanto en tanto se sienta en un banco o en el claustro para tomar notas, y mientras pasea por la ciudad se detiene en un bar o en un rincón apartado y anota también en su libreta la información que le servirá luego como memorando para la redacción definitiva del capítulo en el que se reflejarán sus impresiones y la realidad de lo que ha visto y lo que le ha sucedido.

De las ciudades describe el paisaje urbano, su estado de conservación, el ambiente, la actividad comercial, el ajetreo de las calles:

Mientras que por Chamberí los pocos que se veían eran personas mayores, paseantes madrugadores o mujeres que compraban el periódico y el pan, por la calle Hortaleza y Gran Vía son jóvenes que todavía siguen de juerga o que vuelven a sus casas con los rostros demacrados [...] Ya en la Puerta el Sol, más adelante, donde Madrid tiene su corazón, unos y otros se mezclan con los turistas y con los sindicalistas que ya se agrupan con sus banderas y distintivos ondeando $[\ldots]^{37}$

En las descripciones de paisajes la naturaleza posee siempre historia, está animada, provoca emociones sensoriales ${ }^{38}$ :

En la hora dudosa del atardecer, la vieja ciudad castellonense, el bastión en la frontera entre Valencia y Aragón, la arriscada sede episcopal que tantas gestas viviera antes de sucumbir a su decadencia de hoy, flota más que se asienta en su emplazamiento rocoso rodeada de montañas que se borran como ella poco a poco mientras que en las riberas del río Palancia comienzan a iluminarse los pueblos y pedanías de alrededor ${ }^{39}$.

El reflejo especular de su mirada frente al paisaje se intensifica ante aquel que le trae recuerdos personales y en el que proyecta sus sentimientos ${ }^{40}$, como al contemplar desde Segorbe el pico de Espadán, el lugar donde su padre combatió en la guerra y estuvo a punto de morir:

El viajero lo mira con melancolía. El viajero a estas alturas del atardecer, empieza a sentir el peso de la memoria y se arrepiente de no haber escuchado más a su padre cuando debía,

\footnotetext{
${ }^{36}$ J. Llamazares, Las rosas del sur, ob. cit., p. 459.

${ }^{37}$ J. Llamazares, Las rosas del sur, ob. cit., pp. 13-14.

${ }^{38}$ Sobre el paisaje en la obra de Llamazares véase: M. A. Suárez Rodríguez, La mirada y la memoria de Julio Llamazares: paisajes percibidos, paisajes vividos, paisajes borrados (memoria de una destrucción y destrucción de una memoria), León, Universidad de León, 2004 [Tesis doctoral]. I. Andres Suárez, «La prosa de Julio Llamazares», en F. Sevilla Arroyo y C. Alvar Ezquerra (eds.), Actas del XIII Congreso de la Asociación Internacional de Hispanistas, Madrid, 6-11 de julio de 1998, Madrid, Castalia, 2000, vol. 2, pp. 476-485.
}

${ }^{39}$ J. Llamazares, Las rosas del sur, ob. cit., p. 288.

${ }^{40}$ P. Phillips, «La memoria del paisaje en los viajes de Julio Llamazares», en Marrero Henríquez, J. M. (coord.), Pasajes y paisajes: espacios de vida, espacios de cultura, Servicio de publicaciones de la Universidad de Gran Canaria, Las Palmas de Gran Canaria, 2006, pp. 105-124. V. q. A. Ares Ares, «Motivos clásicos en la novela Distintas formas de mirar el agua de Julio Llamazares», en Lectura y signo: revista de literatura, n. 12/ 1 (2017), pp. 49-55. 
cuando todavía podía contarle historias de la guerra, de esa guerra que vivió con solo diecinueve años y que le trajo desde su pueblo leonés hasta esta sierra castellonense que el viajero ahora contempla, violeta en la lejanía, ensoñadora y fantasmal a un tiempo ${ }^{41}$.

Entre los personajes descritos destaca el viajero. Su imagen física aparece en las fotografías que la fotógrafa Cecilia Orueta, su mujer, a la que está dedicada la obra, realizó para ilustrar la obra, y que nos permiten contemplar lugares, escenas, personajes y detalles que se describen en los diferentes capítulos. El autor también nos ofrece un breve perfil suyo en contraste con el comportamiento de los turistas en el interior de la catedral de La Almudena de Madrid: «escéptico, reflexivo, respetuoso y hasta lento en el andar» ${ }^{42}$. Y no obstante su interés humanista por la religión, la espiritualidad y los temas relacionados con ella, de su credo religioso nos dice: «no cree en los favores, y menos si los hace una talla de madera (distinto es que le guste que otros lo crean) $\gg^{43}$. Por otra parte, a lo largo de la obra se revelan muchas otras facetas de su carácter, por ejemplo, el sentido del humor y la ironía, entre otras.

Los personajes históricos que «pueblan» las catedrales, sea porque estén enterrados en ellas o porque hayan dejado allí sus obras (reyes y nobles, obispos, santos y mártires, literatos, pintores, arquitectos, orfebres, vidrieros, escultores...), son tan numerosos que en el imaginario medieval compondrían la más extraordinaria danza de la muerte. Echamos a faltar por ello un índice alfabético que, como los mapas que ilustran los itinerarios de los viajes, facilitaría la consulta y nos daría una idea en perspectiva de la importancia que han tenido determinados personajes y artistas en la historia de las catedrales españolas. También son numerosos los personajes con los que se encuentra el viajero. De querer llevar a cabo una clasificación de estos últimos, se podrían agrupar en tres categorías: los que trabajan en la catedral, que son religiosos, sacristanes y personal de la catedral o del museo catedralicio, como taquilleros, vigilantes, personas de la limpieza o guías; los visitantes, entre los que distinguimos parroquianos, peregrinos y turistas; y los que están fuera de la catedral, a la entrada -como los mendigos o algún artista- o en el resto de la ciudad: libreros, personal de museos, restauradores y ciudadanos normales que el viajero encuentra por la calle, en parques o jardines; $y$, por último, los familiares y amigos del viajero que viven en las ciudades que visita.

Las relaciones que él entabla con ellos son también muy variadas, yendo de las exclusivamente comerciales a las personales, y de simples intercambios verbales de cortesía a conversaciones más largas y confidenciales. En las interacciones breves

\footnotetext{
${ }^{41}$ J. Llamazares, Las rosas del sur, ob. cit., p. 289.

${ }^{42}$ J. Llamazares, Las rosas del sur, ob. cit., p. 18.

${ }^{43}$ J. Llamazares, Las rosas del sur, ob. cit., p. 18.
} 
usa en general el discurso indirecto, traza en breves líneas el retrato del personaje y cita solo aquellas frases que proporcionan la información relevante o aportan algunas otras connotaciones: humor, complicidad, ironía, recelo. Solo transcribe diálogos más largos cuando el interés del personaje o del tema lo merecen, y lo hace a imitación de los intercambios verbales reales: considerando el tono y el habla del sujeto, dotándolos de la personalidad de aquel. Como hace con Manolo, el guía autodidacta de la catedral de Ciudad Rodrigo, que el autor define como «una extraña mezcla de pícaro y maestrescuela»y al que dedica el capítulo, «El guía de Ciudad Rodrigo» ${ }^{44}$.

- ¿Qué ve usted en esa esquina?

- Una imagen.

- ¿Y en la otra?

- Otra imagen.

- ¿Y ahí?

- ¿Ahí? -dice el viajero, mirando a donde señala-. Nada.

- Claro. Porque no hay nada -le sonríe Manolo, divertido ${ }^{45}$.

Y también con Jesús, el encargado y guía del museo de la catedral de Badajoz, cuya pronunciación y cuya timidez hacen que nos resulte un personaje afable y simpático ${ }^{46}$. Entre los personajes que retrata con mayor detalle se encuentran el mosén de Roda de Isábena, José María Lemiñana, que rescató de la ruina la excatedral ${ }^{47}$; Justo Gallego, «un quijote» que desde hace cincuenta años está construyendo él solo, con la esporádica ayuda de algún vecino, «una catedral» enorme en Mejorada del Campo ${ }^{48}$; don Tomás Leal, el cura de la catedral de Burgo de Osma ${ }^{49}$, al que el autor ya había conocido quince años atrás cuando escribía Cuadernos del Duero ${ }^{50}$ y que colecciona refranes que empiezan por «Más vale...» $\mathrm{O}$ «Vale más...»; y algunos personajes curiosos, como el mago Merlín de Mondoñedo ${ }^{51}$, librero de Cunqueiro; Salvador, que le hace de guía desinteresadamente en la catedral de San Salvador de Oviedo, propietario del café Sevilla donde iba el autor cuando estudiaba Derecho en esa ciudad ${ }^{52}$; D. Felipe Albarrán Vargas-Zúñiga, encargado de protocolo del arzobispado Mérida-Badajoz ${ }^{53}$; así como muchos de los amigos del viajero: el pintor Sendo en Astorga, Cerebro en

\footnotetext{
${ }^{44}$ J. Llamazares, Las rosas de piedra, ob. cit., p. 198-207.

${ }^{45}$ J. Llamazares, Las rosas de piedra, ob. cit., p. 210.

${ }^{46}$ J. Llamazares, Las rosas del sur, ob. cit., p. 139 y ss.

${ }^{47}$ J. Llamazares, Las rosas de piedra, ob. cit., p. 513 y ss.

${ }^{48}$ J. Llamazares, Las rosas del sur, ob. cit., p. 69 y ss.

${ }^{49}$ J. Llamazares, Las rosas de piedra, ob. cit., p. 321 y ss.

${ }^{50}$ J. Llamazares, Cuadernos del Duero, León, Edilesa, 1999.

${ }^{51}$ J. Llamazares, Las rosas de piedra, ob. cit., p. 90 y ss.

${ }^{52}$ J. Llamazares, Las rosas de piedra, ob. cit., p. 118 y ss.

${ }^{53}$ J. Llamazares, Las rosas del sur, ob. cit., p. 141 y ss.
} 
Badajoz, Alejandro en Córdoba o Iñaki en Menorca. Todos estos personajes, junto con otros anónimos, constituyen una seleccionada muestra de tipos y caracteres de nuestro país.

\section{CARACTERÍSTICAS PRAgMALINGÜÍSTICAS Y LÉXICAS}

La narración gira en torno a la tercera persona en lugar de la primera, que es más habitual en los libros de viajes. Esto le permite al narrador convertirse también en un personaje literario a la par que el resto y desplazar de sí mismo el centro deíctico. La suya es una visión especular y omnisciente, el narrador conoce todo acerca del viajero, los hechos que refiere, cómo se mueve, lo que hace, lo que ve y lo que siente, y lo describe mediante la demonstratio ad oculos (Bühler, 1983) 54 :

Con las manos en los bolsos, caminando muy despacio y deteniéndose cada poco para volver a admirar lo visto, el viajero recorre una por una las vidrieras, que se deslizan ante sus ojos como si fueran un libro abierto. El viajero va embriagado por la luz que las alumbra (luz de Dios, diría un creyente) y por la música que ahora suena, que parece elegida para ello ${ }^{55}$.

De este modo logra que los lectores también «vean» lo que él describe, al igual que, más adelante, cuenta cómo un grupo de ciegos «ve» la catedral de Ciudad Rodrigo siguiendo las explicaciones del guía:

[...] se les ve felices. Felices de estar aquí y de escuchar lo que los ojos no pueden ver, pero que el guía les va contando. A cambio, piensa el viajero con cierta envidia, no les afecta la oscuridad que invade ya todo el templo a esta hora ya avanzada de la tarde ${ }^{56}$.

Las referencias contextuales al espacio y al tiempo, dentro y fuera de las catedrales, no difieren de las de sus precedentes libros de viajes: en toda su obra el espacio es a la vez físico y social, y comprende, además de los elementos estructurales materiales o de la naturaleza, las gentes, la cultura, el lenguaje, el modo de vida, los sentimientos. Y mientras que las catedrales son la memoria de las ciudades, el tiempo es el olvido. El papel del arquitecto, del artista o del escritor es fundamental, ya que intentan atrapar el tiempo fugitivo, dejar un testimonio del mismo. En la Seo de Urgel el autor se pregunta, pensando en el monje que ilustró el Beato de Liébana: «¿Cómo iba a suponer que tantos siglos después sus creaciones continuarían existiendo, conservadas como tesoros en una urna? ¿Será eso la posteridad? $\gg^{57}$.

\footnotetext{
${ }^{54}$ K. Bühler, Teoria del linguaggio [1983], Roma, Ed. Armando Mondadori, 2009.

${ }^{55}$ J. Llamazares, Las rosas de piedra, ob. cit., p. 128-129.

${ }^{56}$ J. Llamazares, Las rosas de piedra, ob. cit., p. 215.

${ }^{57}$ J. Llamazares, Las rosas de piedra, ob. cit., p. 641.
} 
El tópico clásico del Ubi sunt? («¿Dónde están o qué fue de...?») que posee una amplia tradición en la literatura española ${ }^{58}$, junto con otros relacionados con él, recurre a menudo dentro de las catedrales, esas rosas de piedra llenas de belleza y obras de arte en todas sus manifestaciones, que son a la vez cementerios llenos de panteones de personajes ilustres. Y la respuesta a la pregunta Ubi sunt? se halla en muchos de los epitafios de estos, como el de Gil Rodríguez de Junterón, el arcediano de Lorca enterrado en Murcia («Aquí viene a parar la vida») ${ }^{59}$. El autor lo sugiere asimismo con las imágenes del crepúsculo que, tras revestir por unos instantes de oro las obras de arte y las efigies de los notables sepultados en las catedrales, los deja a oscuras a los ojos del mundo.

Pero el sentido filosófico más espiritual del Ubi sunt?, el de contemptus mundi o «desprecio del mundo», se encuentra solo en una de las numerosas tumbas de cardenales de la catedral de Toledo, la del arzobispo Portocarrero: «HIC IACET PULVIS, CINIS ET NIHIL; es decir, "aquí yace polvo, ceniza y nada" $»^{60}$. En relación con el tópico se halla el de la fugacidad de la vida (tempus fugit): los sepulcros empotrados en los muros de las naves y capillas de la catedral de León le recuerdan al visitante «lo efímera que es la vida $»^{61}$. Y también el de la vanidad del mundo (Vanitas vanitatum omnia vanitas), que se halla explícitamente en el epitafio del canónigo Juan de Grajal en la misma catedral de León: «iOh, tú, quienquiera que seas, que pasas y contemplas la mezquina superficie de este mármol, mira adónde va la vana gloria de este mundo!» ${ }^{62}$. En contraste con ellos, se halla el tópico del carpe diem, que invita a gozar del momento, en el capítulo que el autor dedica a la catedral-mezquita de Córdoba, «Córdoba carpe diem» ${ }^{63}$.

En la visita a la catedral de Tuy, que titula «La barca del Miño» ${ }^{64}$, el autor ilustra el tempus fugit virgiliano a través de una alegoría: el viajero en busca de la calma y la soledad se acerca hasta el río Miño, que delimita la frontera entre España y Portugal, y, tumbándose en la orilla, se abandona contemplando el río y todas las cosas -incluida la catedral- reflejadas en él como flotando en el agua. El tiempo se desliza con la corriente y la catedral es la barca que arrastra el río del tiempo, de la historia, hacia el Más Allá, hacia la nada o la eternidad:

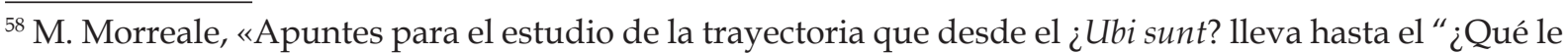
fueron sino...?" de Jorge Manrique», Thesaurus, Tomo $30 / 3$ (1975), pp. 471-519.

${ }^{59}$ J. Llamazares, Las rosas del sur, ob. cit., p. 339.

${ }^{60}$ J. Llamazares, Las rosas del sur, ob. cit., p. 166.

${ }^{61}$ J. Llamazares, Las rosas de piedra, ob. cit., pp. 131-132.

${ }^{62}$ J. Llamazares, Las rosas de piedra, ob. cit., p. 140.

${ }^{63}$ J. Llamazares, Las rosas del sur, ob. cit., p. 451 y ss.

${ }^{64}$ J. Llamazares, Las rosas de piedra, ob. cit., pp. 40-53.
} 
Tendido sobre la hierba, con la cabeza sobre una piedra y el alma llena de agua, el viajero, cumpliendo al fin su objetivo, se va quedando traspuesto, contemplando cómo el río va llevándose sus penas y, con ellas, las imágenes que se reflejan en su superficie: los chopos, la Comandancia Naval, las barcas de la ribera, el perfil de las higueras y las casas y esa gran mole de piedra, desafiante, que domina la ciudad y el horizonte, pero que se desgaja de él como si fuera una enorme barca. Una barca que se aleja poco a poco hacia el océano Atlántico $[\ldots]^{65}$.

La grandeza de ese río que atraviesa las fronteras está implícita también en las reflexiones del viajero, que desea llenarse de agua ${ }^{66}$ y fluir en la corriente que comunica las dos orillas, los dos países ${ }^{67}$, mientras corre hacia el océano. El río tiene un papel significativo en la obra de Llamazares: El río del olvido (1990) y Cuadernos del Duero (1999) tienen como protagonistas los ríos. La vida es como un río (vita flumen) que corre fugaz hacia la muerte ${ }^{68} \mathrm{y}$ las catedrales son como naves, barcas de piedra, que plasman la transformación que opera el tiempo por la mano del hombre y los avatares de la historia. La metáfora de la barca de piedra se repite y amplía en el interior de las catedrales de Valladolid, Córdoba y Guadix, cuando el viajero se duerme en su interior (Somnium, imago mortis) y se despierta confundiendo el sueño y la realidad, como expresa en este pasaje con claros ecos calderonianos:

En cualquier caso la breve siesta le ha hecho despertar confuso, como si la mezquita fuese una ensoñación fantástica, un lugar fuera del tiempo y de la realidad a la que intenta regresar. ¿Qué es más ficticio, se pregunta mientras la contempla, lo que está viendo o lo que soñó? ${ }^{69}$

Por lo que se refiere al lenguaje, Llamazares muestra una vez más su acercamiento filológico a la lengua ${ }^{70}$ y un conocimiento y manejo encomiables del léxico especializado relativo a la geografía, al urbanismo de las ciudades, a la arquitectura, a la historia y al arte. Su sensibilidad lingüística se revela en numerosos particulares: transcribe frases en gallego, catalán y valenciano, y epitafios latinos con su traducción. Recoge términos en catalán, vasco e incluso leonés ${ }^{71}$. Remite a la etimología árabe o latina de muchos

\footnotetext{
${ }^{65} \mathrm{~J}$. Llamazares, Las rosas de piedra, ob. cit., pp. 48-49.

${ }^{66}$ La imagen del alma llena de agua recuerda un pasaje del Viaje a Italia de Goethe en Roma cuando exclama: «Como una botella se llena pronto cuando se sumerge abierta debajo del agua, así puede llenarse uno en Roma cuando es sensible y está preparado. El elemento artístico nos envuelve por todas partes» (J. W. Goethe, Viaje a Italia, Madrid, 1891, Librería de la Viuda de Hernando y C. a, vol. II, p. 176).

${ }^{67}$ Llamazares es un admirador de Portugal y de la literatura portuguesa y hace un homenaje a este país en su libro Tras-os-Montes. Un viaje portugués (Barcelona, Alfaguara, 1998).

${ }^{68}$ Véase J. E. Cirlot, Diccionario de símbolos, Barcelona, Siruela, 2006, p. 360, s.v. pantano.

${ }^{69}$ J. Llamazares, Las rosas del sur, ob. cit., p. 469.

${ }^{70}$ En un libro reciente (J. Llamazares, Atlas de la España imaginaria, Madrid, Nórdica Libros, 2015), recorre el país siguiendo la huella de lugares geopoéticos, lugares imaginarios que corresponden a tópicos lingüísticos (Los Cerros de Úbeda, Babia, las Batuecas, Pinto y Valdemoro, Jauja, la ínsula Barataria, Fuenteovejuna), pero que existen en la realidad.
}

${ }^{71}$ En J. Llamazares, Las rosas de piedra, ob. cit., p. 126, encontramos el término leonés entrecallar. 
topónimos (Magerit de Madrid, Ebusus, Yebisah de Ibiza; Septem de Ceuta, etcétera). Explica el significado de palabras dialectales (figas 'amuletos'; riuà 'riada'; panza de burro 'nubes persistentes'), y de términos locales referidos a tradiciones (mascletá 'disparo pirotécnico', trobigueres 'ligas', poteo 'irse de vinos') o de la gastronomía (esgarrat 'plato de bacalao', orelletes 'dulce valenciano', garum 'salsa de vísceras fermentadas de pescado'), entre otros muchos. También se interesa por nombres de plantas (vinagrellas) o por el significado de términos que desconoce (Pandorga, una fiesta de Ciudad Real). Refiere además abundancia de refranes y frases hechas relacionadas con los lugares, como tirar de la manta, cuyo origen descubre en Tudela ${ }^{72}$.

Sus diálogos, por otra parte, reproducen las particularidades fonéticas del habla de los personajes que encuentra, como la del cochero gitano en Palma de Mallorca: «- ¿Un paseo, cabayero? -Le tienta otro de los cocheros arrastrando gitanamente la y...» ${ }^{73}$; y de nuevo más tarde: «Venga, amigo, dese una vueltesita...» ${ }^{74}$; o la del guía del museo de Badajoz: «La vizit dura cuarencinco minut y comprendel muzé y la catedral...» ${ }^{75}$. Y en ellos muestra también una particular atención al tono y al registro del lenguaje, el cual se adapta constantemente a las circunstancias. Por otra parte, ironiza sobre el lenguaje hueco que aparece en algunas guías de viaje ${ }^{76}$ y sobre los anglicismos superfluos ${ }^{77}$.

En cuanto a las figuras retóricas, en la obra hay abundancia de tropos, entre los que destacan las metáforas referidas a las catedrales (rosas de piedra, bosque de piedra, naves, relicarios, cementerios, reductos de paz). Algunas de ellas provienen de conceptos filosóficos clásicos, como libro de historia ${ }^{78}$, ciudad de Dios, Jerusalén celeste ${ }^{79}$. Otras, como nave (ya lexicalizada) o la barca de la alegoría de «la barca del Miño», forman parte del acervo clásico de las metáforas náuticas ${ }^{80}$. Asimismo, abundan las figuras de pensamiento: las sinestesias: «se oye latir el aire» ${ }^{81}$, «una llanura infinita de cereal

\footnotetext{
${ }_{72}$ J. Llamazares, Las rosas de piedra, ob. cit., p. 414.

${ }^{73}$ J. Llamazares, Las rosas del sur, ob. cit., p. 369.

${ }^{74}$ J. Llamazares, Las rosas del sur, ob. cit., p. 377.

${ }^{75}$ J. Llamazares, Las rosas de piedra, ob. cit., p. 139.

${ }^{76}$ J. Llamazares, Las rosas de piedra, ob. cit., p. 147.

${ }^{77}$ J. Llamazares, Las rosas del sur, ob. cit., p. 266.

${ }^{78}$ Véase E. R. Curtius, Literatura europea y Edad Media latina, México-Madrid-Buenos Aires, Fondo de Cultura Económica, 1981, vol.1, cap. XVI, «Il libro come simbolo», pp. 423-489.

${ }^{79}$ Véase nota 11.

${ }^{80}$ Véase E. R. Curtius, Literatura europea y Edad Media latina, ob. cit. vol.1, cap. VII «Metáforas náuticas», pp. 189 y ss.
}

${ }^{81}$ J. Llamazares, Las rosas de piedra, ob. cit., p. 127. 
y añil [...]» ${ }^{82}$; los símiles: «[...] cuya portada barroca se alza frente a sus ojos como un retablo de piedra abierto a la escalinata» ${ }^{83}$; las personificaciones: «El palacio de la Almudaina y la catedral se miran también con aburrimiento [...]» ${ }^{84}$, y otras muchas que requerirían un estudio aparte. De entre todas ellas queremos destacar una figura particular y recurrente en la poesía y en la prosa de Llamazares: la de la anamnesis ${ }^{85}$, que es cuando el autor 'rememora', 'recuerda' un pasado que no ha vivido, como en este pasaje de la visita a la Seo de Urgel:

Sentado en el primer banco, después de tomar sus notas, el viajero se deja llevar por sus pensamientos. Con la ayuda de la música, estos se van hacia el pasado, hacia la época en que se construyó este templo, cuando los Pirineos eran aún un territorio casi inaccesible y por sus valles pastaban libres los caballos de sus moradores $[\ldots]^{86}$.

Y en la misma catedral, frente a la hermosa imagen de la Virgen de Andorra, tras contemplar la copia del Beato de Liébana, el viajero se ve a sí mismo escribiendo el libro como el monje copista del Beato:

[El viajero]... se sumerge poco a poco en el silencio mientras se ve a sí mismo como aquel monje que, en su celda medieval y lebaniega, dibujaba en un pergamino a la luz de una vela, durante horas, las figuras que adornarían el texto del Apocalipsis sin saber adónde irían a parar $^{87}$.

Esa anamnesis tiene lugar en momentos y ante obras o paisajes que le impresionan particularmente, como sucede también al contemplar el tapiz románico de la Creación (s. XI), en la catedral de Gerona:

[...] lo que ocurre sucede en otra época, la de la creación del mundo, cuando la Tierra no tenía forma y el mar y el cielo se confundían en la inmensidad el tiempo; un tiempo que aún no existía porque tampoco existía la vida, como tampoco existían la noche, ni el sol, ni las estaciones. Todo era una amalgama, un magma de luz y sombras que envolvía el silencio puro e inmenso del firmamento. ¡Qué sensación de grandiosidad! ${ }^{88}$

El subjetivismo y la expresividad lingüística ${ }^{89}$, además de mediante el uso de las figuras retóricas, se manifiestan de diversos modos en la descripción, la narración y

\footnotetext{
${ }^{82}$ J. Llamazares, Las rosas del sur, ob. cit., p. 407.

${ }^{83}$ J. Llamazares, Las rosas de piedra, ob. cit., p. 647.

${ }^{84}$ J. Llamazares, Las rosas del sur, ob. cit., p. 369.

${ }^{85}$ La anamnesis parte del concepto filosófico platónico del «saber» como «recordar» el pasado anterior a nosotros, «rememorar» algo no vivido, como un diálogo del alma consigo misma, ya que el alma es inmortal y por ello conoce el pasado, recuerda el mundo perfecto de las ideas. Este concepto ha sido formulado por Platón en el diálogo Menón (vid. Platón, Obras completas, Patricio de Azcárate (ed.), tomo 4, Madrid 1871, pp. 275-345 (Disponible en http:// www.filosofia.org/cla/pla/img/azf04275.pdf)

${ }^{86}$ J. Llamazares, Las rosas de piedra, ob. cit., p. 636.

${ }^{87}$ J. Llamazares, Las rosas de piedra, ob. cit., p. 641.

${ }^{88}$ J. Llamazares, Las rosas de piedra, ob. cit., p. 659.

${ }^{89}$ C. Kerbrat Orecchioni, La enunciación. De la subjetividad en el lenguaje [1980], Buenos Aires, Hachette,
} 
el diálogo. El discurso adquiere su mayor expresividad poética en la descripción de los espacios interiores y las obras artísticas particulares, así como de los paisajes, tal como hemos visto en los ejemplos que hemos transcrito en el apartado correspondiente a las características descriptivas (§. 4). En la narración la expresividad se manifiesta sobre todo mediante la ironía y los apartes, que son más frecuentes cuando el viajero contempla con incredulidad algunas reliquias y la veneración de santos e imágenes religiosas. Por ejemplo, al comentar el contenido de un relicario de la capilla de los Remedios de la catedral de Bilbao, que contiene, dice: "huesos de San Melquíades, San Nemesio, San Saturnino, San Gabino, y ¡de una de las once mil vírgenes! (a saber de cuál de ellas)"190; y en la misma catedral ironiza también acerca de los lemas de las tumbas de algunos obispos: «Lo mejor son sus lemas episcopales: «Dame las almas, quítame todo los demás», el de Gúrpide, y "No he venido a ser servido, sino a servir", el de Añoveros ${ }^{91}$.

El narrador incluso bromea con su propio personaje, como al entrar en la catedral de San Sebastián: «Detrás de él, sobre la puerta, un frío cartel indica: Por favor, apague el móvil. Para hablar con Dios no lo necesita. El viajero obedece, no porque vaya a hablar con Dios, sino por educación» ${ }^{92}$. Pero es en los diálogos donde aparecen más a menudo la ironía y el humor, incluso la provocación, como sucede en la catedral de Valencia, cuando pone en entredicho ante un feligrés la autenticidad del Santo Grial, que se venera allí y también en otros templos (entre ellos el de San Isidoro de León):

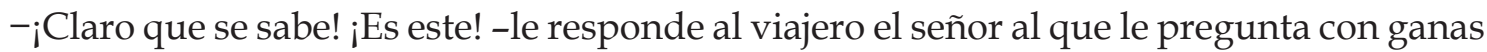
de provocar más que de resolver su duda.

-Pues en León dicen que es el que tienen ellos...

-¡Sí, hombre, sí, ahora nos van a quitar el cáliz...! -contesta contrariado el hombre ${ }^{93}$.

Un pasaje particularmente humorístico es el que narra la visita guiada por el claustro de la catedral de Ciudad Rodrigo con Manolo, el guía autodidacta, que hemos citado arriba, que va mostrando a los turistas las figuras de los capiteles del claustro o los tesoros del museo como un showman:

- ¡Aquí el árbol de la vida!... ¡Aquí una perdiz cantando al reclamo!... ¡Aquí un estudiante que se quedó dormido y se cae con el libro para atrás!... ¡Aquí, una serpiente devorando a una mujer!... ¡Aquí, una mujer devorando a un hombre! [...] ¡Mirad qué libros!...jMirad qué cuadros!...jMirad aquí qué bordados! ${ }^{94}$

1986.

${ }^{90} \mathrm{~J}$. Llamazares, Las rosas de piedra, ob. cit., p. 367.

${ }^{91}$ J. Llamazares, Las rosas de piedra, ob. cit., p. 367.

${ }^{92}$ J. Llamazares, Las rosas de piedra, ob. cit., p. 375.

${ }_{93}$ J. Llamazares, Las rosas del sur, ob. cit., pp. 308-309.

${ }^{94}$ J. Llamazares, Las rosas de piedra, ob. cit., pp. 212 y ss. 
La exclamación, la hipérbole y la valoración apreciativa o ponderativa explícita no suelen ser frecuentes en los textos de Llamazares, pero en esta obra aparecen a menudo combinados con la amplificación cuando contempla la grandeza o belleza de los edificios y obras de arte, como al entrar en la enorme catedral de Sevilla:

No solo es espectacular, sino que corta el aliento al verla por primera vez. Y es que sus dimensiones son tan fabulosas que incluso alguien como el viajero, que ha visto ya catedrales de todos los tipos, de todos los tamaños y colores, se queda paralizado al ver estas cinco naves que ciertamente parecen soñadas por unos locos ${ }^{95}$.

También abunda la interrogación retórica, pero sin apelación al lector; el autor la usa para plantearse cuestiones ante la realidad que observa, para introducir una reflexión o hacer ilaciones, como en la Seo de Urgel, pensando en el Beato de Liébana, en el pasaje que hemos citado arriba ${ }^{96}$.

\section{LA IMAGEN DE EsPAÑA}

Son muchos los paisajes y ciudades, catedrales, monumentos, sucesos y personajes históricos, escritores, filósofos, artistas y personajes reales que desfilan a lo largo de este viaje por España, y del conjunto de todos ellos se obtiene una visión poliédrica, caleidoscópica, del país mismo y de sus principales características, así como de los problemas que le afectan o que poseen mayor relieve de carácter social. El viajero nos va dando esa visión de España a través de la descripción de la realidad que observa, de los libros que lee o comenta durante el viaje y de las gentes con las que se encuentra en los lugares que visita, dentro y fuera de la catedral. A continuación, analizaremos sintéticamente los temas más recurrentes en la obra.

\subsection{LAS CATEDRALES Y SU FUNCIÓN}

Llamazares lee a través de las catedrales la historia de la ciudad desde la época en que estas se construyeron. Las catedrales, los edificios más sublimes que se conservan, y su arquitectura tiene una finalidad espiritual, fueron edificadas como representación de la ciudad de Dios, la Jerusalén celeste. En su origen eran lugares de acogida, en ellas se hacían reuniones gremiales y asambleas del pueblo. Eran centros de estudio, y eran también espacios de recogimiento, incluso refugio para los perseguidos o sostén para los menesterosos, como confirman todavía los nombres de plazas y puertas: de la Limosna en Oviedo o la de la Almoina (cat. 'limosna') en Valencia. La catedral era también centro artístico e intelectual. Constituía una ciudad sagrada y simbólica dentro de la ciudad. Sin embargo, advierte el autor reiteradamente, en el s. xxI las catedrales se

\footnotetext{
${ }_{95}$ J. Llamazares, Las rosas de piedra, ob. cit., p. 478.

${ }^{96}$ Las rosas de piedra, ob. cit., p. 641.
} 
están convirtiendo, como otros edificios religiosos (monasterios, conventos y algunas iglesias), en museos, en los que hay que pagar una entrada para acceder, hay que someterse a unos horarios estrictos y la mayor parte del día permanecen al margen de cualquier otra función:

En los 16 años que he empleado en recorrer todas las españolas he visto cómo iban cerrándolas y cómo se convertían en edificios vacíos de toda espiritualidad (religiosa o profana, tanto da) sin otro destino que el de generar dinero. Los mercaderes del templo hoy son los propios obispos ${ }^{97}$.

En opinión de Llamazares, cerrar las catedrales a los feligreses, o dejarles entrar estrictamente para los oficios religiosos, a horas intempestivas, con las naves en penumbra como en las catacumbas, se convierte en una sustracción al pueblo de su belleza y su función, además de ser un grave error, ya que los cabildos están dando la imagen negativa de una Iglesia que mira a la parte lucrativa y se aparta con ello de la misma ortodoxia cristiana:

Si la mezquita de Córdoba era una mina recaudatoria, la catedral de Sevilla no se queda atrás. Deberían poner la entrada, rezonga el viajero, en lugar de por la puerta del Príncipe por la del Perdón, en la que un relieve representa la expulsión por Jesús de los mercaderes del templo ${ }^{98}$.

Las catedrales están llenas, pero no ya de feligreses, han sido invadidas por los turistas, como las principales ciudades monumentales, y estos no muestran devoción alguna, ni tampoco respeto: pasean por el recinto hablando por el móvil y haciéndose fotografías ante las imágenes, como sucede en Madrid, Toledo, Valencia, Córdoba, Sevilla, Granada y en todas las grandes ciudades turísticas.

Llamazares concluye su obra con la descripción de las procesiones del Viernes Santo en la catedral de La Laguna, en las que participa mucha gente, pero que él mira con escepticismo: el hecho de que estas celebraciones congreguen a mucha gente y participen en ellas, en su opinión no se debe considerar un signo de religiosidad, ya que acuden también muchos por el espectáculo en sí. Las autoridades religiosas, sin embargo, lo interpretan como muestra de la devoción, queriendo hacer ver que el laicismo de nuestra sociedad no es tal:

El obispo expresa su satisfacción por ver la catedral llena, lo que demuestra, según él, que el laicismo de la sociedad española del que tanto se habla no es cierto. Incluso muchos de los que se creen ateos no lo son, afirma, «pues luego son los primeros en portar a hombros la cruz de Cristo en estos días» ${ }^{99}$.

\footnotetext{
${ }^{97}$ J. Llamazares, «Catedrales», El País. Opinión (7 de abril, 2018).

${ }^{98}$ J. Llamazares, Las rosas del Sur, ob. cit., p. 477.

${ }^{99}$ J. Llamazares, Las rosas del sur, ob.cit., p. 680.
} 


\subsection{EL PATRIMONIO ARTÍSTICO Y SU CONSERVACIÓN Y EXPLOTACIÓN}

Además de serlo ellas por sí mismas, son incontables las obras de arte que se hallan en las catedrales y en los museos catedralicios que visita el viajero, sean de autores anónimos o de renombrados artistas, pintores, plateros e imagineros. Y todas estas obras constituyen un enorme patrimonio artístico que la Iglesia y el Estado han de preservar. En algunas catedrales, como en la de Zamora, donde las capillas están cerradas con verjas, impidiendo ver bien los retablos, sin embargo, en la sala del museo, que guarda valiosos tapices, el viajero echa en falta mayor vigilancia: « ¿Para qué tanta vigilancia en el resto de la catedral si, luego, lo mejor, que es esta sala, está a merced de los visitantes?» ${ }^{100}$. Y también echa de menos instalaciones mejores, con paneles explicativos de los objetos artísticos expuestos: «Porque siendo estos tapices auténticas piezas únicas [...] están expuestos sin protección y, algunos de ellos, sin un cartel que explique de qué se trata» ${ }^{101}$. En catedrales como en la de Segorbe comenta que es tal el desamparo del templo que cualquiera podría estar tentado de llevarse $\operatorname{algo}^{102}$.

Sin embargo, las obras de arte que contienen los templos y la falta de religiosos no habrían de ser óbice, en opinión del autor, para que las catedrales, regidas por la iglesia, siguieran cumpliendo con la función para la que fueron creadas en su día gracias al mecenazgo y a las donaciones y limosnas de los ciudadanos. Y alaba aquellas catedrales que, como la de Murcia, aún siguen vivas, es decir, permanecen abiertas a sus feligreses: «Da gusto ver esta catedral, abierta y viva como una iglesia rural, no como tantas otras convertidas ya en museos religiosos» ${ }^{103}$.

\subsection{CREENCIAS RELIGIOSAS, SUPERSTICIONES Y LEYENDAS}

El viajero respeta la religión y a los creyentes, aunque él no lo sea; defiende que la catedral sea un centro espiritual, sin embargo, a su mirada no se oculta la superstición que encierran muchas creencias, como el culto de las reliquias, y usa a menudo la ironía en vez de una crítica directa, subrayando el hecho de que se multipliquen, como los cuerpos de santos o el cáliz del Santo Grial, y manifiesta su estupor ante algunas colecciones, como la de la catedral de Coria, donde, entre otras reliquias, se veneran: un fragmento del lignum crucis, el mantel de la Última Cena, una espina de la corona de Cristo, una ampolla con leche de la Virgen y una pluma del arcángel San Gabriel:

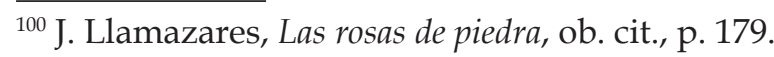

${ }^{101}$ J. Llamazares, Las rosas de piedra, ob. cit., p. 179.

102 J. Llamazares, Las rosas del sur, ob. cit., p. 283.

${ }^{103}$ J. Llamazares, Las rosas del sur, ob. cit., p. 335.
} 
«[El viajero] las contempla una tras otra sin saber si sentirse objeto de una gran broma o caer rendido ante ellas implorando el perdón del cielo» ${ }^{104}$.

Asimismo, deplora abiertamente la exhibición de las momias o partes del cuerpo de los mártires: «Una cosa es la veneración y otra, distinta, la necrofilia, piensa alejándose del lugar» ${ }^{105}$. También le produce rechazo la historia de las emparedadas de Astorga y La Laguna, mujeres que vivieron encerradas en un espacio reducidísimo como castigo y penitencia por sus pecados. En cambio, se regocija con las diversas leyendas que descubre sobre las catedrales, como la del topo en la de León o el lagarto en la de Sevilla, o la de Pedro Díaz, el obispo de Ciudad Rodrigo que resucitó el día de su funeral dejando aterrorizados a los feligreses ${ }^{106}$. Y también le divierten las vidas de algunos santos, como la de santa Librata, que se venera en Sigüenza, de la que el guía de la catedral le comenta que es una santa «muy complicada» y que podría haber sido «la primera anoréxica de la historia», añadiendo que tuvo ocho hermanas que nacieron todas el mismo día y todas fueron santas. $\mathrm{Y}$ en este punto, y ante los gestos de incredulidad de los presentes, el guía comenta, con una sonrisa: «Para Dios nada es imposible» ${ }^{107}$.

\subsection{LA MEMORIA Y LA GUERRA CIVIL}

Llamazares es un observador atento de la situación social y política española, lo cual se refleja en los artículos periodísticos que escribe semanalmente para El País. Sobre todo es perspicaz y analítico cuando se trata de relacionar los hechos del pasado con el presente, como demuestra aquí al indagar acerca de la percepción de las gentes, religiosas y laicas, de una y otra ideología, y de diferentes comunidades de España, sobre los sucesos violentos acaecidos durante la Segunda República, la Guerra Civil y la postguerra. Toda su obra es una batalla contra el olvido, y su interés por la historia en torno a la Guerra Civil se remonta ya a la primera de sus novelas, Luna de lobos (Seix Barral, 1985), donde cuenta la historia de los maquis, y ha sido tema de muchos de sus cuentos y artículos periodísticos ${ }^{108}$.

\footnotetext{
$\overline{104}$ J. Llamazares, Las rosas del sur, ob. cit., pp. 128-129.

${ }^{105}$ J. Llamazares, Las rosas del sur, ob. cit., p. 546.

${ }^{106}$ J. Llamazares, Las rosas de piedra, ob. cit., p. 206.

${ }^{107}$ J. Llamazares, Las rosas del sur, ob. cit., p. 262.

108 Véase C. Carcamo, «Del aforismo a la ficción: la memoria en Julio llamazares», en Espéculo. Revista de estudios literarios, 33 (2006), Universidad Complutense de Madrid. Sobre la guerra civil véase también C. Ravenet Kenna, El viaje de las memorias en Llamazares, Madrid, Ed. Verbum, S. L., 2018; F. Valls Guzmán, «El eco de la guerra civil (Algunos ejemplos: Julio Llamazares, Pilar Cibreiro y Antonio Muñoz Molina)», en La realidad inventada, Análisis crítico de la novela española actual, Barcelona, Crítica (Letras de humanidad), 2003. pp. 56-62; C. B. Rodas, «La Guerra civil en la novela española actual: ¿metáfora o mito?», en VV. AA.: De historias y ficciones. Estudios literarios españoles, San Juan, Universidad Nacional de San Juan (Argentina), 2001, pp. 51-66; V. Possi, El maquis en la novela contemporánea. De Julio Llamazares a Almudena Grandes, Madrid, Wisteria Ediciones, 2017.
} 
La España de la Guerra Civil, símbolo de las grandes contraposiciones ideológicas y de posiciones políticas fundadas en ideales vividos hasta el presente como valores absolutos y convertidas en visiones maniqueístas de la lucha entre el bien y el mal, aparece en su obra en numerosas ocasiones ${ }^{109}$, y de nuevo aquí, en las catedrales, por las señales de destrucción que dejó el fuego o la artillería en esos templos, donde a menudo se refugiaban soldados de uno $\mathrm{u}$ otro bando durante la contienda, y por las lápidas conmemorativas que recuerdan en ellos los asesinatos de religiosos durante el 34 y el 36. En catedrales que fueron incendiadas, como la de Alcalá, que perdió numerosas obras de arte, y que ha sido restaurada recientemente, el autor interroga sobre los sucesos a la gente del lugar que se encuentra en la catedral:

- ¿Ardió todo?

-Casi todo. Imagine usted que la temperatura alcanzó los tres mil grados según dicen... Hasta el tejado se vino abajo.

-Lo que me extraña es que quedara algo... - dice el viajero, impactado, contemplando la catedral en torno.

-Poco, prácticamente nada, ya digo (...) Y mataron a varios canónigos.

- ¿También?

-También. Seis o siete por lo menos... A uno de ellos delante de esa puerta.

- ¿Y usted cómo sabe tanto? -le pregunta el viajero, cada vez más intrigado. Quizá sea un cura, sopesa.

-guía -responde el otro muy serio ${ }^{110}$.

Un poco después, conversa sobre las circunstancias del mismo incendio con el encargado de una librería de la ciudad, que le da una versión distinta de los hechos:

-La catedral la quemaron los milicianos porque un grupo de rebeldes se habían hecho fuertes en la torre, donde establecieron una ametralladora. Eso por no hablar de los curas, que participaron de modo activo en la rebelión - dice el hombre, al que se ve que le molesta el maniqueísmo con el que muchos cuentan la historia.

-Las cosas hay que contarlas bien.

-Por supuesto -dice el viajero que está de acuerdo con él-. Pero ¿y las demás iglesias?

-Eso ya fue otro cantar... Fue por la indignación del pueblo por el comportamiento de la Iglesia en esos días y, antes, durante la República ${ }^{111}$.

En la catedral de Jaén le sorprende que una lápida conmemore, junto con los religiosos asesinados, a los caídos de la parte de los vencedores. Y que en ella con retórica franquista se denomine «una revolución marxista» a lo que fue un levantamiento militar, un golpe de Estado, cuando la Ley de Memoria Histórica obliga a quitar de los sitios públicos las alusiones partidistas en aras de la reconciliación. Pero la iglesia, que se denomina «conciliadora», mantiene todavía lápidas «a los caídos por

\footnotetext{
${ }^{109}$ Véase S. G. Payne, La guerra civil española, Madrid, Ed. Rialp S.A., 2014, pp. 143 y ss.

${ }^{110} \mathrm{~J}$. Llamazares, Las rosas del sur, ob. cit., p. 56.

${ }^{111}$ J. Llamazares, Las rosas del sur, ob. cit., p. 63.
} 
la patria» dentro de las iglesias. Y sobre este tema el viajero constata, al interrogar al sacristán, que continúa existiendo un muro de resentimiento e intransigencia:

- ¿No cree que deberían quitar lo de «revolución marxista»? - le pregunta no a él [el oficiante] sino al sacristán, cuando termina la misa, un viajero decidido a meter el dedo en la llaga, aunque sin imaginar que tanto: el sacristán que se ha detenido al verlo, le mira con ojos de estupefacción.

- ¿Usted piensa eso? - responde- Pues me parece muy bien. Pero yo no voy a hablar con usted - añade, echando a andar hacia la sacristía. ${ }^{112}$.

La postura del sacristán de Jaén contrasta con la del mosén de la catedral de Solsona. En esta población de Cataluña, donde los sucesos durante la guerra fueron incluso más sangrientos que en otras regiones, se quemaron conventos e imágenes sacras y hubo numerosos asesinatos, el párroco, catalanista, habla en cambio de aquello restándole importancia:

- ¿Aquí mataron a muchos curas?

-Muchos - contesta el párroco-. Aunque, cuando llegaron los otros - dice- no fue mejor.

$-i$ Y eso?

-Me acuerdo cuando entraron los franquistas en Solsona. Yo era pequeño, pero recuerdo que mi padre, que era de derechas, al verlos desfilar con las banderas, dijo: «Pobre Cataluña» ${ }^{113}$.

En el claustro de la catedral de Oviedo, la cual, dice Llamazares, para algunos es el símbolo de la monarquía y para otros del republicanismo y de la legendaria rebeldía asturiana, ante una lápida en homenaje a más de un centenar de curas asesinados en las revueltas del 34, el autor hace una reflexión pesimista:

Hoy que todo aquello ha pasado (lo de las guerras y las insurrecciones), al viajero le parece que esta vieja catedral, como todas las de España, no es sino un ejemplo más de las grandezas y miserias de este complejo país y de las contradicciones que han conformado su historia y que, posiblemente, continuarán conformándola muchos siglos ${ }^{114}$.

Acerca del tema Llamazares se interesa por conocer todas las opiniones, y no solo en las catedrales, sino también en los lugares donde se libraron cruentas batallas, como en la sierra de Espadán, donde su padre combatió, salvándose de milagro, ya que murieron casi todos los soldados de su compañía, salvo él y otro telegrafista que estaban tratando de reparar la radio y se habían quedado atrás, en la descubierta:

\footnotetext{
$\overline{112}$ J. Llamazares, Las rosas del sur, ob. cit., p. 438.

113 J. Llamazares, Las rosas de piedra, ob. cit., p. 626.

${ }^{114}$ J. Llamazares, Las rosas de piedra, ob. cit., p. 113.
} 
Es decir, que si el viajero está aquí mirando Segorbe es gracias a esa casualidad que permitió a su padre seguir con vida y reanudarla cuando la guerra terminó. Segorbe sin embargo, ya no recuerda esos días, aquellas fechas tan desoladas y tan sangrientas $[\ldots]^{115}$.

En un reciente artículo publicado en El País, «La España hemipléjica», retoma el tema, dejando clara su posición a favor de la reconciliación y de la Ley de la Memoria Histórica, reivindicando el derecho también de los vencidos a encontrar y dar una sepultura digna a sus familiares asesinados durante la guerra y en la inmediata postguerra como represalia y venganza, y al hacerlo recuerda de nuevo a su padre:

(...) una persona que hizo la guerra con los nacionales, lo que no le impidió condenar las barbaridades que hicieron los suyos ni dejar de buscar a un hermano del otro bando desaparecido y querer por igual a los otros independientemente de la trinchera en la que combatieron $^{116}$.

\subsection{Desigualdad, EMigración, Despoblación}

Las diferencias entre las regiones ricas y pobres de la Península, que el autor ya ha denunciado innumerables veces también en sus artículos periodísticos ${ }^{117}$, son patentes en esta obra que recorre las diversas comunidades de España. El abandono sufrido por el mundo rural español en muchas comunidades cuya economía se basaba en la agricultura ha creado una situación gravísima: catorce provincias españolas tienen más de un $80 \%$ de los municipios en riesgo de extinción. La España rural emigra a las grandes ciudades industriales y pierde población a un ritmo de 45.000 habitantes cada año. Las comunidades de Extremadura, Andalucía y Castilla-La Mancha, son las más afectadas. Dentro de esta última la Alcarria conquense y la Serranía de Guadalajara se encuentran entre las comarcas más pobres, como constata el viajero mientras las recorre $^{118}$.

La riqueza de otras comunidades se advierte también en sus catedrales, como en la de Madrid, en las vascas de Bilbao y San Sebastián, y en las catalanas, que lucen recién restauradas. Otras lo están siendo en el 2003, como la de Vitoria, con un presupuesto de cinco mil millones (pesetas), mientras que, tal como comenta el autor: «la mitad de ese presupuesto es la que tienen para las once catedrales de Castilla y León» ${ }^{119}$. También dentro de comunidades ricas, como la valenciana, observa gran

\footnotetext{
${ }^{115}$ J. Llamazares, Las rosas del sur, ob. cit., p. 274.

${ }^{116}$ J. Llamazares, «La España hemipléjica», El País, 09/02/2019.

${ }^{117}$ Entre ellos, J. Llamazares, «La España de las desigualdades», El País. Opinión, 05/01/2019, donde afirma: «El estado de las autonomías, tan alabado por casi todos durante un tiempo, se está convirtiendo en el de las desigualdades sin que nadie parezca querer corregir esa inercia, tan peligrosa además de injusta».

118 J. Llamazares, Las rosas del sur, ob. cit., p. 250.

${ }^{119}$ J. Llamazares, Las rosas de piedra, ob. cit., p. 347.
} 
diferencia entre las ciudades del interior y las capitales de la costa, como, por ejemplo, entre Segorbe y Valencia, ambas sedes episcopales, una pobre y la otra muy próspera. Las desigualdades se advierten sobre todo en los campos de las diferentes comarcas, bien cultivados o abandonados, pero también en el interior de las ciudades, como en Calahorra y en Tudela, entre la zona antigua (más pobre) y la nueva, o en Orihuela, en el barrio de población mayoritariamente gitana, donde se encuentra la modesta casamuseo de Miguel Hernández.

Como consecuencia de la desigualdad de las regiones surgen los problemas de la emigración y la despoblación de los lugares más pequeños o menos desarrollados. La emigración tiene un gran peso en las regiones más ricas, donde en las calles, establecimientos e incluso en las catedrales, el viajero encuentra con frecuencia a gentes que provienen de otras regiones de España, como en la catedral de San Sebastián, en la de Bilbao, en Lérida, en Solsona, en la Seo de Urgel, en Gerona o en Barcelona y en Madrid.

\subsection{LA IDENTIDAD}

El viaje es, al mismo tiempo, una travesía por la historia de España desde la época de las catedrales (ss. XII y XIII) y los reinos de entonces, hasta el momento actual y las distintas comunidades que la conforman, algunas de ellas, como el País Vasco y Cataluña, caracterizadas por su marcado nacionalismo. En el cuarto viaje de Las rosas de piedra, «Vascos, navarros y riojanos», que comprende el territorio que fue el antiguo Reino de Navarra, al llegar a Vitoria el viajero constata la pujanza del nacionalismo vasco en el ambiente de las calles y bares, «La mayoría de ellos independentistas, a juzgar por los carteles y las pintadas que los jalonan», y asiste al acto de homenaje al fallecido político y escritor Mario Onaindía, del que dice: «simboliza en su trayectoria la tragedia de este pueblo dividido y enfrentado frontalmente» ${ }^{120}$. También en Cataluña el nacionalismo se manifiesta abiertamente, inclusive en el clero: «Desde Ripoll [el monasterio], la senyera se sucede en todos los pueblos, remarcando el carácter catalanista de todos ellos y poniéndole al paisaje una nota de color...» ${ }^{121}$. En el resto de las regiones no advierte una posición tan marcada, si bien es cierto que la actual subdivisión territorial de las Comunidades Autónomas, que no obedece, salvo en algunos casos, a un criterio histórico, y la desigualdad económica entre ellas, ha fomentado rivalidades y alianzas.

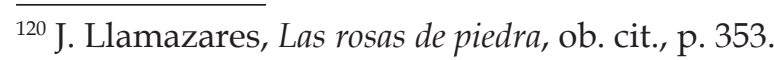

${ }^{121}$ J. Llamazares, Las rosas de piedra, ob. cit., p. 645. 
La diversidad cultural y lingüística y la idiosincrasia de las diversas regiones históricas constituyen para el autor una gran riqueza, junto con la diversidad de paisajes, gentes y costumbres, pero no entra en la discusión política, aunque no se muestra partidario de patrias ni de fronteras, ni siquiera de las que existen con Portugal, como ya hemos comentado al hablar de la frontera del Miño ${ }^{122}$. En el preámbulo a Las rosas de piedra, advierte, «para que nadie malinterprete»:

Cuando me refiero a España, lo hago como territorio, el que lleva ese nombre en la actualidad, sin entrar en la discusión política existente sobre su identidad, como tampoco entro en la de su actual división autonómica. De hecho me guío por la división antigua, más coherente a mi parecer, que por la que está en vigor, demasiado artificial en muchos $\operatorname{casos}^{123}$.

Llamazares, que no tiene una patria, porque su pueblo yace bajo las aguas de un pantano, el del Porma, en una entrevista de Manuel de la Fuente con motivo de la publicación de su novela Las lágrimas de San Lorenzo (2013) ${ }^{124}$, afirmaba, respecto al significado para él de la palabra patria:

La memoria es la única patria de todas las personas que hemos renunciado a todas. [...] Para un escritor, la patria es su memoria, la patria son esos lugares a los que deseas volver porque allí has sido feliz, y creo que la patria no tiene nada que ver con la falsa idea del patriotismo vinculada a tierras y fronteras ${ }^{125}$.

La historia y el arte, la mezcla de estilos que se hallan en las catedrales y que describe el viajero, nos llevan a considerar que han sido las diversas culturas, sobre todo la romana, la árabe, junto con la del occidente de Europa y el Mediterráneo, principalmente a través de las peregrinaciones y el comercio, las que han ido construyendo y reconstruyendo la identidad del país, conformando no solo los pueblos y ciudades, sino también el carácter de las gentes. Y de manera particular hay que destacar la huella que ha dejado la cultura islámica que pervivió durante ocho siglos y especialmente en las ciudades de Levante y del centro-sur, muchas de las cuales eran grandes capitales de antiguas taifas. Las catedrales, construidas sobre las mezquitas, todavía conservan las plantas y elementos de las mismas (arcos, puertas, yeserías y torres), como sucede en las de Valencia, Murcia o Sevilla. La mezquita de Córdoba constituye un símbolo del sincretismo entre las culturas islámica y cristiana; aunque ese adulteramiento inquiete al autor, que lo siente como una agresión de una fe a la otra.

\footnotetext{
${ }^{122}$ J. Llamazares, Las rosas de piedra, ob. cit., pp. 40-53.

${ }^{123}$ J. Llamazares, Las rosas de piedra, ob. cit., p. 18.

${ }^{124}$ J. Llamazares, Las lágrimas de San Lorenzo, Barcelona, Alfaguara, 2013.

${ }^{125}$ Entrevista en Abc. Cultura (11/4/2013).
} 
Como advierte Lleó Cañal (2008) ${ }^{126}$ en un artículo referido a las ruinas de Roma y extensivo a otras grandes civilizaciones como la islámica, en las confrontaciones entre imperios y credos religiosos, los símbolos del poder y de la fe fueron eliminados y sustituidos por los de los conquistadores, a menudo aprovechando los mismos materiales. El hombre medieval, observa Lleó, no sentía remordimientos al destruir estos edificios:

Era difícil para un hombre medieval sentir nostalgia o dolor por las ruinas imperiales, puesto que estas eran testimonios de «la ciudad de los hombres», cuya aniquilación había defendido San Agustín como paso imprescindible para el triunfo de la «Ciudad de Dios» y eran, además, el refugio de los dioses paganos, ídolos a los que se les atribuía poderes demoníacos.

Pero no obstante la destrucción de templos paganos no se eliminó la cultura romana, ni con la destrucción de las mezquitas los reyes cristianos pudieron eliminar la influencia de la cultura árabe. Los mudéjares y moriscos, que se integraron en la España cristiana tras la Reconquista, hicieron que el arte islámico perviviera en la arquitectura hasta el s. XVI, dando prueba de ese rico mestizaje entre culturas en las ciudades como Tudela y en numerosos monumentos, como las catedrales de Teruel y Tarazona o en la capilla mozárabe de la catedral de Toledo, donde todavía se celebra la misa con rito hispanomozárabe desde la época de Cisneros ${ }^{127}$, y pervive incluso en los libros miniados religiosos, como misales, antifonarios y libros de oraciones, creados por monjes mozárabes en los scriptorium de los monasterios, como el Antifonario mozárabe de la catedral de León ${ }^{128}$. Y no solo en el arte, sino en la agricultura, en la artesanía y en la lengua hallamos las huellas de la pervivencia de su cultura hasta el día de hoy.

Por otra parte, en las catedrales se observa también el mestizaje entre la cultura y el arte de los reinos medievales de Castilla y Aragón en ciudades como Orihuela, donde el viajero encuentra una mezcla de estilos que revelan su historia: el gótico valenciano predomina en su arquitectura, pero a este se suman el rococó y renacimiento de varios retablos y el barroco de algunas imágenes ${ }^{129}$. Y al describir la ciudad afirma:

Su silueta es, por ello, celtíbera, griega, cartaginesa, romana, visigoda, árabe, aragonesa y castellana, pues tales son las culturas que durante más o menos tiempo la dominaron

\footnotetext{
${ }^{126}$ V. Lleó Cañal, «Quanta Roma fuit, ipsa ruina docet, el impacto de las ruinas en la sensibilidad artística moderna», en Boletín de la Real Academia Sevillana de Buenas Letras: Minervae Baeticae, 36 (2008), pp. 93 108. La cita que transcribimos se encuentra en pp. 95-96.

127 J. Llamazares, Las rosas del Sur, ob. cit., p. 181.

${ }^{128}$ J. Llamazares, Las rosas de piedra, ob. cit., p. 140. Véase. M. C. Lacarra Ducay (Coor.), Arte mudéjar en Aragón, León, Castilla, Extremadura y Andalucía, Zaragoza, Institución «Fernando el Católico» (C.S.I.C.), 2006.

${ }^{129}$ J. Llamazares, Las rosas del Sur, ob. cit., p. 317.
} 
y conformaron, si bien la influencia de algunas haya sido mayor que la de otras. En concreto, las tres últimas son las que más impronta dejaron en ella, sin duda por haber sido las más recientes; la árabe por los aprovechamientos y en el cultivo de la feraz huerta del Segura, cuyo paisaje modificaron y conformaron tal como es hoy, y la aragonesa y la castellana en la fisonomía urbana de la ciudad ${ }^{130}$.

La idiosincrasia de las Islas Baleares es asimismo el resultado de una mezcla de culturas que la han conformado a través de los siglos, la cartaginesa, la romana, la árabe y la catalana, como se percibe en Ibiza:

Esa belleza que aún pervive en algunas zonas, muy pocas, del interior y del norte de la isla en las que es posible evocar la Ebusus cartaginesa y romana y la Yebisah árabe musulmana de la que de cuando en cuando aparecen restos arqueológicos y de las que heredó el nombre y una cultura que se entrelaza con la catalana que implantó al conquistar la isla el obispo de Tarragona Guillén de Montgrí el año $1235^{131}$.

En cuanto a las gentes, en Las Palmas de Gran Canaria, una isla que levantaron hombres -dice- que tenían «un pie en la mitología y otro en la historia», y por donde han cruzado tantos pueblos, no encuentra el autor ni entre los mayores que siguen las funciones de la Semana Santa en la catedral, ni entre los jóvenes que llenan los bares, diferencias en el comportamiento con los del resto de la nación:

[...] estos que ahora aguardan frente a su fachada a que pase la procesión que viene de Santo Domingo y recorre las viejas calles de Vegueta hasta la medianoche, o los que sin interés en ella, buscan la diversión en los bares y restaurantes en grupos animadísimosen nada se diferencian ya salvo en el acento de todos los que el viajero ha visto a lo largo y ancho de la nación en la que se integran. ${ }^{132}$

Al llegar al final del viaje, en San Cristóbal de La Laguna ${ }^{133}$, el autor hace un balance del recorrido por esa España invertebrada que ha contemplado:

Por el camino quedan paisajes de todo tipo, verdes y ásperos, secos y húmedos, marinos y montañosos, helados y calurosos, sobrepoblados y semidesérticos. Y en ellos, gentes de todas las clases, amables y displicentes, hurañas y hospitalarias, educadas y desagradables. La España poliédrica que hoy acaba aquí, en esta hermosa ciudad trazada con tiralíneas en lo que fuera el lecho antiguo de una laguna, de ahí su apellido, se extiende como un mapa en la memoria del viajero y sobre él las setenta y tres ciudades que ha visitado antes de llegar a esta $[\ldots]^{134}$.

\footnotetext{
${ }^{130}$ J. Llamazares, Las rosas del sur, ob. cit., p. 314.

${ }^{131}$ J. Llamazares, Las rosas del sur, ob. cit., p. 388.

132 J. Llamazares, Las rosas del sur, ob. cit., p. 671.

133 Una circunstancia que remite, por contraste, a Vegamián, el pueblo del escritor, sumergido por un pantano, al contrario de La Laguna que surge en un antiguo lago desecado. Véase J. Llamazares, Distintas formas de mirar el agua (2015).

134 J. Llamazares, Las rosas del sur, ob. cit., p. 673.
} 
Ese mapa que Llamazares ha diseñado es un mosaico que muestra los paisajes y las gentes de España, su historia y su situación social y económica: variedad de paisajes de todo tipo, ciudades llenas de monumentos y bellísimas catedrales, costumbres antiguas y rica gastronomía, fiestas y celebraciones; pero también desigualdades entre las comunidades y en el interior de las mismas, aglomeraciones urbanas, emigración, despoblamiento rural, rencores encubiertos desde la Guerra Civil, conflictos nacionalistas. Sin embargo, entre las gentes, el viajero no halla diferencias relevantes de comportamiento por el hecho de ser de unas regiones u otras, excepto las políticas. Será porque viajar, como decía otro gran escritor, Antonio Tabucchi, sirve, entre otras cosas, para hacernos comprender con mayor claridad que nadie posee nada, que el hombre en todas partes está de manera provisional:

[...] posar los pies en el mismo suelo durante toda la vida puede provocar un peligroso equívoco, el de hacernos creer que esta tierra nos pertenece, como si no la tuviéramos en préstamo, al igual que todo en la vida lo tenemos en préstamo ${ }^{135}$.

En San Cristóbal de La Laguna, Llamazares prueba esa desposesión, junto con la melancolía del que sabe que ese largo viaje que emprendió hace diecisiete años por la geografía española ha terminado, y se siente lejos de todo el mundo, viendo cómo la estela de su nave se desdibuja tras él mientras camina sin rumbo en la noche:

[...] San Cristóbal de la Laguna, un entramado de caserones y de palacios con varios siglos a sus espaldas y cierto aire ultramarino en el que la vegetación confirma que el viajero está ahora tan cerca de América como de Europa; es decir, tan lejos de todo el mundo como se siente en este momento mientras camina por La Laguna sin rumbo bajo la noche ${ }^{136}$.

\section{CONCLUSIONES}

Son diversos los aspectos que habría que destacar de esta gran obra de Llamazares. Para empezar la admiración y el respeto que siente por esas «rosas de piedra» que son expresión del espíritu humano más sublime, edificios maravillosos que contienen el tiempo condensado y que como él muestra, nos dan la clave para conocer la historia de sus ciudades y, en consecuencia, la de España. Por otro lado la reprobación que hace a la mayoría de los cabildos que han olvidado su función originaria y, con su afán de lucro, han convertido las catedrales en museos para turistas, alejándolos así de la población local y apartándose del propio evangelio cristiano de la fraternidad.

Desde el punto de vista sociológico, a través de la mirada del autor se obtiene una visión caleidoscópica de España en sus múltiples facetas. Es la imagen que resulta

\footnotetext{
${ }^{135}$ A. Tabucchi, Viajes y otros viajes, Barcelona, Anagrama, 2012. En Prólogo, p. 10.

${ }^{136}$ J. Llamazares, Las rosas del Sur, ob. cit., p. 690.
} 
de la historia de las catedrales, de la descripción de los paisajes de las distintas regiones, de la situación social y económica de las mismas, del ambiente de las ciudades y de retratos y diálogos con las personas con que se encuentra el viajero. En esa imagen se reflejan los contrastes, la variedad, la riqueza del territorio, y también los problemas socioeconómicos del país: la desigualdad territorial entre regiones ricas y pobres, la emigración, la despoblación, los nacionalismos y la cuestión identitaria, así como la brecha creada en la sociedad española por la Guerra Civil. También se pueden observar en esa mirada, al mismo tiempo, los rasgos principales de los españoles, su carácter y su comportamiento: sus gustos, sus intereses, su laicismo y religiosidad, y también sus maneras de disfrutar y divertirse.

Llamazares, al hacer este viaje por la geografía e historia del país, no está solo: en su discurso se advierte la huella de los escritores que lo han precedido y que han indagado en la intrahistoria de la nación, desde el mismo Cervantes a los noventayochistas Baroja y Unamuno, Machado o el filósofo Ortega y Gasset. Pero Llamazares no pretende darnos una visión parcial y subjetiva, sino que prefiere dejar que la imagen del país surja de la complejidad de los diversos factores que observa y describe al lector, ya que de la combinación de todos ellos surge una imagen más fidedigna, plural y compleja de la realidad y es cada lector quien ha de interpretarla.

Queremos subrayar la arquitectura de la obra en su conjunto, la armonía entre el contenido y la forma y la proporción entre las partes: cada catedral es vista siguiendo un orden temporal similar, lo que otorga a cada visita una estructura circular que se conforma con la filosofía que inspiró la construcción de las catedrales, basándose en la luz, el equilibrio, las proporciones. $\mathrm{Y}$ al mismo tiempo un orden geográfico espacial que va trazando, a medida que avanza de oeste a este y de norte a sur, el perfil del país, tanto físico como histórico y sociológico. Por último, destacaremos la riqueza y precisión del lenguaje, el detalle en las descripciones arquitectónicas y artísticas, la fluidez y expresividad del discurso y el lenguaje poético con el que Llamazares envuelve los espacios y muestra las imágenes, que hace que podamos observar la realidad de España y admirar la belleza de las catedrales reflejada en el agua removida por su mano como en un caleidoscopio.

\section{BibLIOGRAFÍA}

Andres-SuÁrez, I. y CAsas, A., (eds.), El universo de Julio Llamazares. Actas del «Grand Séminaire» de Neuchâtel, 26 de mayo de 1998, vol. 3, Université de Neuchâtel, 1998. 
, «La prosa de Julio Llamazares», en Florencio Sevilla Arroyo y Carlos Alvar Ezquerra (eds.), Actas del xIII Congreso de la Asociación Internacional de Hispanistas, Madrid, 6-11 de julio de 1998, Madrid, Castalia, 2000, vol. 2, pp. 476- 485.

Ares Ares, A., «Motivos clásicos en la novela Distintas formas de mirar el agua de Julio Llamazares», en Lectura y signo: revista de literatura, n. 12/1 (2017), pp. 41- 58. , «En la estela de Cervantes: similitudes y diferencias entre La ruta de Don Quijote de Azorín y El viaje de Don Quijote de Julio Llamazares», en J. Ferrándiz Lozano y J. Payá Bernabé, Azorín, clásico y moderno. Monográfico de Canelobre: Revista del Instituto Alicantino de Cultura «Juan Gil-Albert», 67 (2017), pp. 130-145.

Bueno, G., «Homo viator. El viaje y el camino», Prólogo a Pedro Pisa, Caminos reales de Asturias, Oviedo, Pentalfa, 2000.

BÜHLER, K., Teoria del linguaggio [1983], Roma, Armando, 2009.

CARCAmo, S., «Del aforismo a la ficción: la memoria en Julio llamazares», en Espéculo. Revista de estudios literarios, 33 (2006), Universidad Complutense de Madrid. Disponible en en: http://www.ucm.es/info/especulo/numero33/afollama. html

ÇIRLOT, J. E., Diccionario de símbolos, Barcelona, Siruela, 2006.

Curtius, E. R., Literatura europea y Edad Media latina, 2 vols., México-Madrid-Buenos Aires, Fondo de Cultura Económica, 1981 [3 $3^{\mathrm{a}}$ ed.].

Di Giorgio MartinI, F., Trattati di Architettura, Ingenieria e Arte Militare, Corrado Maltese [ed.], Il Polifilo, Milano, 1967.

Duby, G., La época de las catedrales (Arte y sociedad, 980-1420), Madrid, Cátedra, 1993.

FulCANELLI, El misterio de las catedrales y la interpretación esotérica de los símbolos, París, 1929.

Gómez Moreno, M., Catálogo monumental de España (1870-1970), Disponible en: http:/ / www.bibliotecadigital.jcyl.es.

Kerbrat Orecchioni, C., La enunciación. De la subjetividad en el lenguaje [1980], Buenos Aires, Hachette, 1986.

Lacarra Ducay, M. C. (Coord.), Arte mudéjar en Aragón, León, Castilla, Extremadura y Andalucía, Zaragoza, Institución «Fernando el Católico» (C.S.I.C.), 2006.

Llamazares, J., (2018), Las rosas del sur, Barcelona, Alfaguara, 2018. , «Catedrales», El País. Opinión, 7/4 (2018).

, El viaje de Don Quijote, Barcelona, Alfaguara, 2016. , Distintas formas de mirar el agua, Barcelona, Alfaguara, 2015. , Las lágrimas de San Lorenzo, Barcelona, Alfaguara, 2013. , Atlas de la España imaginaria, Madrid, Nórdica Libros, 2015 , Las rosas de piedra, Barcelona, Alfaguara, 2008. , Escenas de cine mudo, Barcelona, Seix Barral, 1994. 
Lleó Canal, V., «Quanta Roma fuit, ipsa ruina docet. El impacto de las ruinas en la sensibilidad artística moderna», en Boletín de la Real Academia Sevillana de Buenas Letras: Minervae Baeticae, 36, 2008, pp. 93-108.

Morreale, M., «Apuntes para el estudio de la trayectoria que desde el ¿Ubi sunt? Lleva hasta el Qué le fueron sino...? de Jorge Manrique», Thesaurus, Tomo 30/3 (1975), pp. 471-519.

Mortara Garavelli, B., Manual de Retórica, Madrid, Cátedra, 1991.

PAYNe, S. G., La guerra civil española, Madrid, Rialp, 2014.

PAleólogos, K., «Julio Llamazares o la historia que se borró», en Estudios Humanísticos. Filología, 39 (2017), pp. 39-53.

Phillips, P., «La memoria del paisaje en los viajes de Julio Llamazares», en J. M. Marrero Henríquez (coord.), Pasajes y paisajes: espacios de vida, espacios de cultura, Servicio de publicaciones de la Universidad de Gran Canaria, Las Palmas de Gran Canaria, 2006, pp. 105-124.

Possi, V., El maquis en la novela contemporánea. De Julio Llamazares a Almudena Grandes, Madrid, Wisteria, 2017.

Ravenet KenA, C., El viaje de las memorias en Llamazares, Madrid, Verbum, 2018.

RoDAs, C. B., «La Guerra civil en la novela española actual: ¿metáfora o mito?», en VV.AA.: Dehistorias y ficciones. Estudios literariosespañoles, San Juan, Universidad Nacional de San Juan (Argentina), 2001, pp. 51-66.

SuÁrez Rodríguez, M. A., La mirada y la memoria de Julio Llamazares: paisajes percibidos, paisajes vividos, paisajes borrados (memoria de una destrucción y destrucción de una memoria), León: Universidad de León, 2004 [Tesis doctoral].

UnAmuno, M., En torno al casticismo, Barcelona, en «Biblioteca Moderna de Ciencias Sociales», dir. por Santiago Valentì y Camps, vol. IV, 1902. Disponible en: htpp:/www.cervantesvirtual.com.

VAlls GuZMÁN, F., «El eco de la guerra civil (Algunos ejemplos: Julio Llamazares, Pilar Cibreiro y Antonio Muñoz Molina)», en La realidad inventada, Análisis crítico de la novela española actual, Barcelona, Crítica (Letras de humanidad), 2003. pp. 56-62. 